2016-05

Sublethal effects of copper sulphate compared to copper nanoparticles in rainbow trout (Oncorhynchus mykiss) at low $\mathrm{pH}$ : physiology and metal accumulation

\author{
Al-Bairuty, GA \\ http://hdl.handle.net/10026.1/4936
}

10.1016/j.aquatox.2016.02.006

AQUATIC TOXICOLOGY

Elsevier BV

All content in PEARL is protected by copyright law. Author manuscripts are made available in accordance with publisher policies. Please cite only the published version using the details provided on the item record or document. In the absence of an open licence (e.g. Creative Commons), permissions for further reuse of content should be sought from the publisher or author. 


\title{
Sublethal effects of copper sulphate compared to copper nanoparticles in rainbow trout (Oncorhynchus mykiss) at low pH: physiology and metal accumulation
}

\author{
Genan A. Al-Bairuty ${ }^{a}$, David Boyle ${ }^{a}$, Theodore B. Henry ${ }^{\mathrm{a}, \mathrm{b}, \mathrm{c}}$, Richard D. Handy ${ }^{\mathrm{a}, *}$ \\ a Ecotoxicology Research and Innovation Centre, School of Biological Sciences, Plymouth University, Plymouth, UK \\ b School of Life Sciences, Heriot-Watt University, Edinburgh, UK \\ ${ }^{\mathrm{c}}$ Department of Forestry Wildife and Fisheries, and Center for Environmental Biotechnology, The University of Tennessee, Knoxville, TN, USA
}

\section{A R T I C L E I N F O}

\section{Article history:}

Received 23 November 2015

Received in revised form 12 February 2016

Accepted 14 February 2016

Available online 17 February 2016

\section{Keywords:}

Copper

$\mathrm{pH}$

Nanomaterials

Oncorhynchus mykiss

Sodium

$\mathrm{Na}^{+} / \mathrm{K}^{+}$-ATPase

\begin{abstract}
A B S T R A C T
A few studies have investigated the interaction between copper toxicity and water $\mathrm{pH}$ in fishes, but little is known about the effects of acidic $\mathrm{pH}$ on the toxicity of copper nanoparticles (Cu-NPs). This study aimed to describe the sub-lethal toxic effects of $\mathrm{Cu}-\mathrm{NPs}$ compared to $\mathrm{CuSO}_{4}$ at neutral and acidic water $\mathrm{pH}$ values in juvenile rainbow trout. Fish were exposed in triplicate ( 3 tanks/treatment) to control (no added $\mathrm{Cu}$ ), or $20 \mu \mathrm{gl}^{-1}$ of either $\mathrm{Cu}$ as $\mathrm{CuSO}_{4}$ or $\mathrm{Cu}-\mathrm{NPs}$, at pH 7 and 5 in a semi-static aqueous exposure regime for up to 7 days. Acidification of the water altered the mean primary particle size (at pH 7, 60 $\pm 2 \mathrm{~nm}$ and $\mathrm{pH} 5,55 \pm 1 \mathrm{~nm}$ ) and dialysis experiments to measure dissolution showed an increased release of dissolved $\mathrm{Cu}$ from Cu-NPs at pH 5 compared to $\mathrm{pH}$ 7. Copper accumulation was observed in the gills of trout exposed to $\mathrm{CuSO}_{4}$ and $\mathrm{Cu}-\mathrm{NPs}$ at $\mathrm{pH} 7$ and 5 , with a greater accumulation from the $\mathrm{CuSO}_{4}$ treatment than $\mathrm{Cu}-\mathrm{NPs}$ at each $\mathrm{pH}$. The liver also showed $\mathrm{Cu}$ accumulation with both $\mathrm{Cu}$ treatments at $\mathrm{pH} 7$ only, whereas, the spleen and kidney did not show measurable accumulation of $\mathrm{Cu}$ at any of the water $\mathrm{pH}$ values. Exposure to acid water caused changes in the ionoregulatory physiology of control fish and also altered the observed effects of $\mathrm{Cu}$ exposure; at $\mathrm{pH} 5$, branchial $\mathrm{Na}^{+} / \mathrm{K}^{+}$-ATPase activity was greater than at $\mathrm{pH} 7$ and the inhibition of $\mathrm{Na}^{+} / \mathrm{K}^{+}$-ATPase activity caused by exposure to $\mathrm{CuSO}_{4}$ at $\mathrm{pH} 7$ was also not observed. There were some changes in haematology and depletion of plasma $\mathrm{Na}^{+}$at pH 7 and 5 due to $\mathrm{Cu}$ exposure, but there were few material-type or $\mathrm{pH}$ effects. Overall, the data show that the accumulation of $\mathrm{Cu}$ is greater from $\mathrm{CuSO}_{4}$ than $\mathrm{Cu}-\mathrm{NPs}$; however, understanding of the effects of low pH on bioavailability of $\mathrm{CuSO}_{4}$ may not be directly transferred to $\mathrm{Cu}-\mathrm{NPs}$ without further consideration of the physico-chemical behaviour of $\mathrm{Cu}-\mathrm{NPs}$ in acid water.
\end{abstract}

(C) 2016 Elsevier B.V. All rights reserved.

\section{Introduction}

Copper $(\mathrm{Cu})$ is an essential metal that plays an important role in cellular metabolism (Linder and Hazegh-Azam, 1996) but it can also be acutely toxic to freshwater fish in the $\mu \mathrm{gl}^{-1}$ range (see reviews by Handy, 2003; Grosell, 2012). Copper concentrations in freshwater environments typically range from about 0.2 to around $30 \mu \mathrm{gl}^{-1}$ (Bowen, 1985). For waterborne exposures, the target organs for dissolved $\mathrm{Cu}$ are primarily the gill, with the liver also being a central compartment in Cu metabolism (Grosell et al., 1996, 1997; Shaw et al., 2012). However, Cu toxicity to fish is influenced by water

* Corresponding author at: School of Biological Sciences, Plymouth University, Drake Circus, Plymouth PL4 8AA, UK. Fax: +44 1752584605.

E-mail address: r.handy@plymouth.ac.uk (R.D. Handy). chemistry such as alkalinity, hardness, dissolved organic matter and $\mathrm{pH}$ (Erickson et al., 1996). There is general agreement that increasing water hardness or adding dissolved organic matter will reduce the toxicity of dissolved copper (Erickson et al., 1996; Laurén and McDonald, 1985a). The situation is less clear for water pH. In some circumstances, lowering water $\mathrm{pH}$ can protect against acute Cu toxicity; for example, $\mathrm{LC}_{50}$ values at $\mathrm{pH} 4.7,5.7$ and 7.0 were 66.0 , 4.2 , and $2.8 \mu \mathrm{g} \mathrm{I}^{-1}$ in juvenile rainbow trout [Oncorhynchus mykiss (Cusimano et al., 1986)]. Such phenomena are explained by hydrogen ions competing for binding sites on the gill with $\mathrm{Cu}$ ions (the biotic ligand model; Playle and Dixon, 1993). Alternatively, lowering water pH might increase Cu toxicity (Erickson et al., 1996), and at $\mathrm{pH} 4$ or less the toxic $\mathrm{Cu}^{2+}$ ion dominates chemical speciation in the water, promoting Cu uptake at the gill (Bury and Handy, 2010). However, between pH 5 and pH 7, a number of copper hydroxide 
complexes are formed which also alter the toxicity of $\mathrm{Cu}$ (Kamunde and Wood, 2004).

Acidic water alone is known to be toxic to freshwater fishes (Wood and Mcdonald, 1982). Low water $\mathrm{pH}$ is associated with excessive mucus secretion and respiratory distress (Plonka and Neff, 1969). Indeed, waterborne exposure to acid (Chevalier et al., 1985) or dissolved Cu (Figueiredo-Fernandes et al., 2007) can cause damage to the gills of fish. In both cases, loss of gill function can lead to disturbances to ionic regulation and gas exchange (Wood and McDonald, 1982; Laurén and McDonald, 1985b); combinations of acid and $\mathrm{Cu}$ have also been reported to produce haematological disturbances (Nussey et al., 2002). Copper is also known to cause toxicity to fishes via oxidative stress to the internal organs and/or via secondary hypoxia associated with gill injury (Hoyle et al., 2007; Eyckmans et al., 2011; Shaw et al., 2012).

Only a few recent studies have assessed the effects of copper nanoparticles (Cu-NPs) on fishes, and all of these studies are at neutral pH values (Griffitt et al., 2007; Shaw et al., 2012). The mechanisms of Cu-NP toxicity and whether or not there is involvement of the free metal ion remains unclear. A fraction of dissolved $\mathrm{Cu}$ may be released from Cu-NPs (e.g. Shaw et al., 2012), but for rainbow trout at least, $\mathrm{CuSO}_{4}$ appears more acutely toxic than the equivalent concentration of $\mathrm{Cu}-\mathrm{NPs}$, with exposure to $100 \mu \mathrm{gl}^{-1}$ of $\mathrm{CuSO}_{4}$ causing complete mortality, while the same concentration of $\mathrm{Cu}$ as $\mathrm{Cu}-\mathrm{NPs}$ for 10 days caused only $19 \%$ mortality (Shaw et al., 2012). Although the magnitude of effects for $\mathrm{CuSO}_{4}$ compared to $\mathrm{Cu}$-NPs were greater, the types of sub-lethal effects were similar. Both showed $\mathrm{Cu}$ accumulation in the gills, transient changes in haematology and depletion of plasma $\mathrm{Na}^{+}$, disturbances to tissue ion levels, and decreased branchial $\mathrm{Na}^{+} / \mathrm{K}^{+}$-ATPase activity (Shaw et al., 2012). Exposure to $0.25 \mathrm{mg} \mathrm{l}^{-1}$ of dissolved $\mathrm{Cu}$ and either 0.25 or $1.5 \mathrm{mg} \mathrm{l}^{-1}$ of $\mathrm{Cu}-\mathrm{NPs}$ for $48 \mathrm{~h}$ in zebrafish showed similar effects that included inhibition of the branchial $\mathrm{Na}^{+} / \mathrm{K}^{+}$-ATPase activity and gill injury (Griffitt et al., 2007).

The effects of water $\mathrm{pH}$ on the sub-lethal toxicity of Cu-NPs have not been investigated in rainbow trout. It remains unclear whether or not the concept of $\mathrm{pH}$-dependent toxicity will apply to nanomaterials in the same way as traditional dissolved metals (e.g. Playle and Dixon, 1993). The aim of the present study was to determine whether or not $\mathrm{Cu}$ accumulation and sub-lethal responses in rainbow trout upon exposure to Cu-NPs were affected by lowering water $\mathrm{pH}$ from 7 to 5 . Experiments were also conducted to understand the effect of acidity on the rate of dissolution of dissolved $\mathrm{Cu}$ from $\mathrm{Cu}-\mathrm{NPs}$. In addition, given the dearth of detailed physiological data on the combined sub-lethal effects dissolved $\mathrm{Cu}$ and low $\mathrm{pH}$, the $\mathrm{CuSO}_{4}$ control in the present study also contributes to our understanding of metal ion/acid toxicity to trout.

\section{Materials and methods}

\subsection{Experimental design}

Juvenile rainbow trout were obtained from Torre Fisheries Ltd., Watchet, Somerset, UK, and held for 4 weeks prior to experimentation in a stock aquarium containing aerated, dechlorinated Plymouth tap water (see below) and under a photoperiod of $12 \mathrm{~h}$ light: $12 \mathrm{~h}$ dark. Trout were fed to satiation twice daily with a commercial feed (EWOS, Westfield, UK; $2-3 \mathrm{~mm}$ pellets) containing $8 \mathrm{mg} \mathrm{kg}^{-1} \mathrm{Cu}$, as is standard for trout.

For logistical reasons, exposures were conducted first at $\mathrm{pH}$ 7 ( 7 day exposure), and then repeated one week later at $\mathrm{pH} 5$. One day prior to the commencement of exposures, fish weighing $27.4 \mathrm{~g} \pm 0.9$ and with a total length of $13.8 \pm 0.1 \mathrm{~cm}$ (means \pm S.E.M., $n=198$ ) were distributed randomly between nine aerated experimental glass aquaria containing 201 of dechlorinated Plymouth tap water (11 fish/tank), in a triplicate design (3 tanks/treatment). Fish were exposed for up 7 days using a semi-static exposure regime (80\% water change every $12 \mathrm{~h}$ with re-dosing after each change, i.e. twice/day) to: control (no added $\mathrm{Cu}$ ); $20 \mu \mathrm{gl}^{-1}$ of $\mathrm{Cu}$ as $\mathrm{CuSO}_{4} .5 \mathrm{H}_{2} \mathrm{O}$; or $20 \mu \mathrm{gl}^{-1}$ copper nanoparticles ( $\mathrm{Cu}-\mathrm{NPs}$ ). The stock water was adjusted manually to either $\mathrm{pH} 5$ or $\mathrm{pH} 7$ by adding $0.5 \mathrm{M}$ $\mathrm{H}_{2} \mathrm{SO}_{4}$. Furthermore, the $\mathrm{pH}$ was checked every $4 \mathrm{~h}$ during experiments, and adjusted as necessary. The exposure concentration of $20 \mu \mathrm{gl}^{-1}$ of $\mathrm{Cu}$ as $\mathrm{CuSO}_{4}$ or $\mathrm{Cu}-\mathrm{NPs}$ was chosen as a sub-lethal dose that would produce physiological disturbances in trout based on our previous study (Shaw et al., 2012). The acidic pH value, pH 5, was chosen because $\mathrm{Cu}$ accumulation on the gill of trout (exposure) appears to be high at this $\mathrm{pH}$ (Playle and Dixon, 1993), whilst also avoiding the acute mortality associated with lower $\mathrm{pH}$ values. This $\mathrm{pH}$ also seemed to give reasonably stable dispersions of $\mathrm{Cu}-\mathrm{NPs}$ (see Section 2.2).

Fish were not fed in the $24 \mathrm{~h}$ prior to, or during the experiment in order to minimise the risk of incidental ingestion of $\mathrm{Cu}-\mathrm{NPs}$ or $\mathrm{CuSO}_{4}$ with food, and to help maintain good water quality. Water samples were collected before and after each water change to verify the exposure concentrations (see Section 3.1) and monitor temperature, and dissolved oxygen (HACH HQ40d multi reader), and total ammonia (HI95715, Hanna Instruments). There were no treatment differences in water quality between tanks (One-Way ANOVA, $p>0.05$ ). Data were (means \pm S.E.M., $n=576$ samples): temperature, $15.7 \pm 0.2^{\circ} \mathrm{C}$; dissolved oxygen, $96 \pm 0.5 \%$; total ammonia, $0.97 \pm 0.05 \mathrm{mg} \mathrm{l}^{-1}$. The electrolyte composition of the dechlorinated Plymouth tap water was measured by inductively coupled plasma optical emission spectroscopy (ICPOES, Varian 725 ES, Melbourne, Australia), and was: $17.86 \pm 0.01$, $1.67 \pm 0.18,9.90 \pm 0.25 \mathrm{mgl}^{-1}$ for $\mathrm{Ca}^{2+}, \mathrm{K}^{+}$and $\mathrm{Na}^{+}$respectively $\left(0.45,0.04\right.$, and $\left.0.43 \mathrm{mmoll}^{-1}\right)$. Background total water $\mathrm{Cu}$ concentrations in the tanks of control fish were $2.94 \pm 0.28 \mu \mathrm{g} \mathrm{l}^{-1}$ $\left(0.046 \pm 0.004 \mu \mathrm{moll}^{-1}\right)$. Fish were randomly sampled on day 0 (initial fish from the stock), and days 4 and 7 for haematology and plasma ions, tissue electrolytes, and biochemistry.

\subsection{Copper nanoparticles, stock suspensions, and dosing regimes}

The Cu-NPs used here are from the same batch that was used by Shaw et al. (2012). Briefly, the powdered form of Cu-NPs was obtained from Sigma-Aldrich, UK, and had an average particle size $<50 \mathrm{~nm}$ and $99.9 \%$ purity (manufacturer's information). One 1 stock suspensions of $1 \mathrm{~g} \mathrm{l}^{-1}$ were prepared twice daily in lowdensity polyethylene (LDPE) bottles (in order to prevent sticking of Cu-NPs to glass) by dispersing the NPs in ultrapure (Milli-Q) water with stirring (magnetic stirrer IKA Werke RET basic C, at $300 \mathrm{rpm}$ ) for $12 \mathrm{~h}$ prior to dosing. This stock was then used to dose aquaria immediately following water changes. Due to the low concentrations of $\mathrm{Cu}-\mathrm{NPs}$ used in the exposures with fish which exceeded the sensitivities of some analytical instruments, the effects of water $\mathrm{pH}$ on primary particle sizes [by transmission electron microscopy (TEM, JEOL 1200EXII)] and agglomerative state [by Nanoparticle Tracking Analysis (NTA, NanoSight LM10, Nanosight, Salisbury, $\mathrm{UK})$ ] were investigated in $1 \mathrm{~g} \mathrm{l}^{-1}$ stocks prepared in ultrapure water and stirred for $12 \mathrm{~h}$ as described above, followed by dilution into $\mathrm{pH}$-adjusted Plymouth tap water to a concentration of $0.1 \mathrm{gl}^{-1}$ and stirring whilst gassing with air for a further $12 \mathrm{~h}$ i.e. to match the $12 \mathrm{~h}$ of stirring prior to dosing tanks and the additional $12 \mathrm{~h}$ between water changes. At $1 \mathrm{gl}^{-1}$, Cu-NPs had primary particle diameters of: $61 \pm 4 \mathrm{~nm}$ for stock dispersions in Milli-Q water, and in dispersions at $\mathrm{pH} 7$ and 5 in Plymouth tap water following dilution to $0.1 \mathrm{gl}^{-1}$ the diameters were $60 \pm 2$ and $55 \pm 1 \mathrm{~nm}$, respectively (mean \pm S.E.M, $n=68-123$, Fig. 1). Measured mean agglomerate sizes of NP stock dispersions were: $138 \pm 16 \mathrm{~nm}$ in Milli-Q water, $143 \pm 3 \mathrm{~nm}$ at $\mathrm{pH} 7$, and $114 \pm 11 \mathrm{~nm}$ at $\mathrm{pH} 5$. 

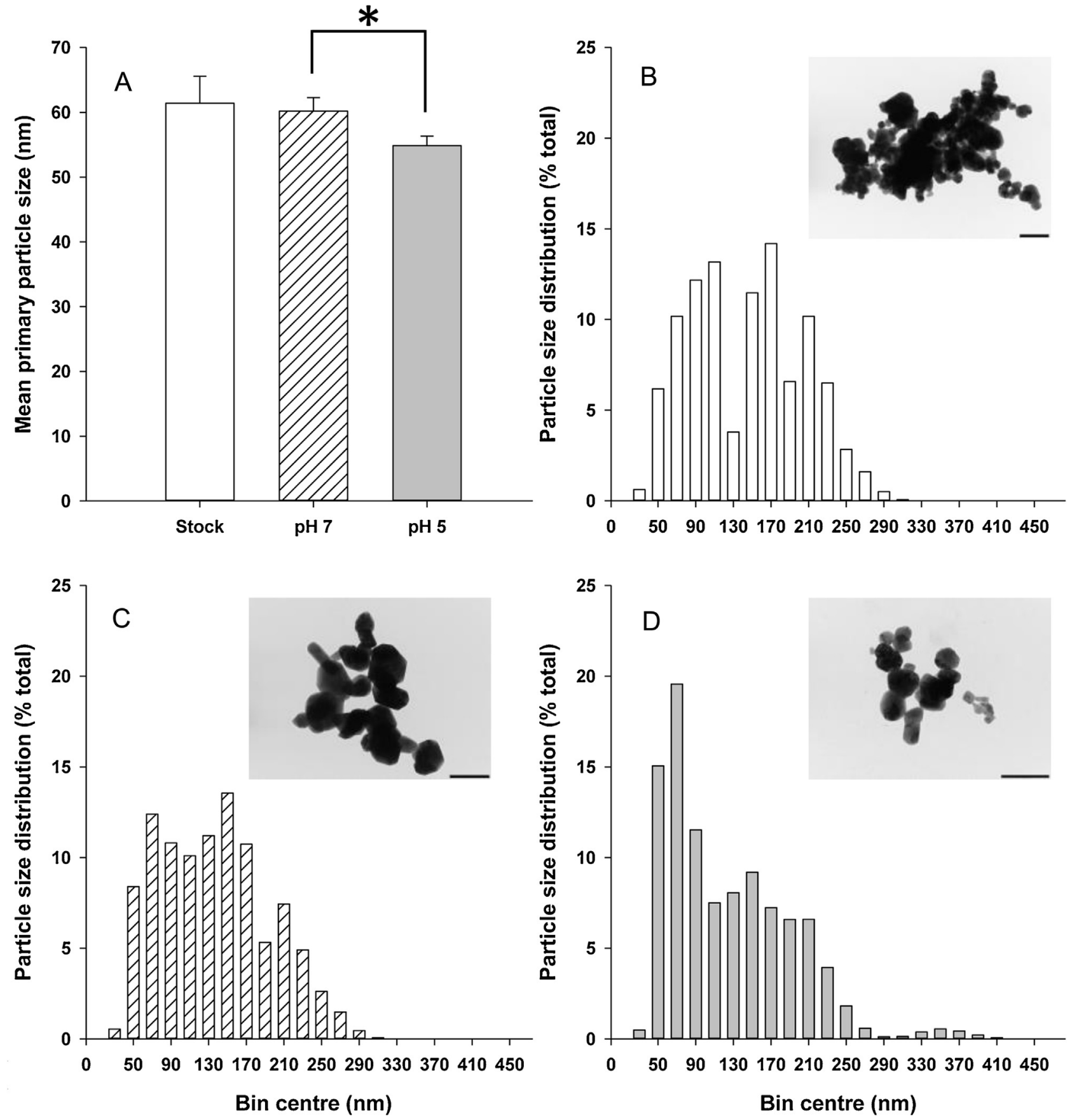

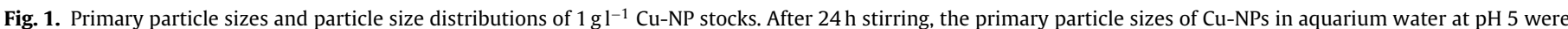

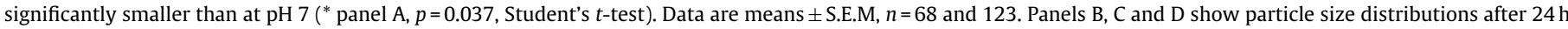

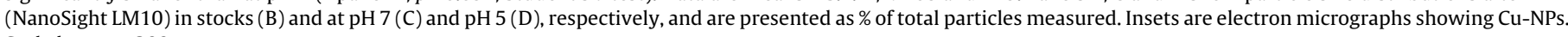
Scale bars are $200 \mathrm{~nm}$.

A $1 \mathrm{~g} \mathrm{l}^{-1}$ dissolved $\mathrm{Cu}$ stock solution was prepared by dissolving $\mathrm{CuSO}_{4} \cdot 5 \mathrm{H}_{2} \mathrm{O}$ (Sigma-Aldrich) in 11 of ultrapure (Milli-Q). The same $\mathrm{CuSO}_{4}$ stock solution was used in both 7 day exposures at $\mathrm{pH} 7$ and $\mathrm{pH}$ 5. Tanks were dosed with $\mathrm{CuSO}_{4} \cdot 5 \mathrm{H}_{2} \mathrm{O}$ at $12 \mathrm{~h}$ intervals following water changes as described above for $\mathrm{Cu}-\mathrm{NPs}$.

\subsection{Dissolution of $\mathrm{Cu}$ from $\mathrm{Cu}$-NPs at different $\mathrm{pH}$}

Dialysis experiments were conducted to measure the dissolution rate of $\mathrm{Cu}$ from the $\mathrm{Cu}-\mathrm{NPs}$ in dechlorinated Plymouth tap water at pH 7 and 5 (see Section 2.1) and as described by Handy et al. (1989) with modifications for NPs as reported by Besinis et al.
(2012). All glassware and equipment were acid washed (5\% nitric acid) and triple rinsed in deionised (Milli-Q) water before use. A stock of Cu-NPs was prepared and dispersed as described in Section 2.2 and then $8 \mathrm{ml}$ of the stock diluted to $100 \mathrm{mg} \mathrm{l}^{-1}$ of $\mathrm{Cu}-\mathrm{NPs}$, or a no added $\mathrm{Cu}$ control (i.e. the test solution with no copper) were filled into dialysis bags [ $70 \times 25 \mathrm{~mm}$ cellulose dialysis tubing with a $12 \mathrm{kDa}$ molecular weight cut off (Sigma-Aldrich, St. Louis, USA)] and both ends of each dialysis bag secured with Medi-clips to prevent any leakage. The bags were then placed in a beaker containing $492 \mathrm{ml}$ water at the appropriate $\mathrm{pH}$ (total volume $500 \mathrm{ml}$ ). The solutions in the beakers were gently agitated with a multi-point magnetic stirrer for $24 \mathrm{~h}$ at room temperature and samples of the 
external solution taken from each beaker at $0,0.5,1,2,3,4,6,8$ and $24 \mathrm{~h}$. The $\mathrm{pH}$ was monitored throughout. This is an extended dialysis period compared to the regimen used for the exposure (i.e. $80 \%$ water change at $12 \mathrm{~h}$ intervals) to better compare the behaviours of NPs at pH 7 and 5 and the fate of NPs in the residual $20 \%$ of water remaining in tanks between water changes. Samples were analysed by ICP-OES for total $\mathrm{Cu}$ concentrations.

\subsection{Haematology and blood plasma analysis}

Haematology and blood plasma analyses of trout were performed as described in Handy and Depledge (1999). Two fish were randomly collected from each tank ( $n=6$ fish/treatment and $n=6$ initial fish) at days 4 and 7 from each pH experiment, and terminally euthanized with MS222 $\left(0.2 \mathrm{~g} \mathrm{l}^{-1}\right) \mathrm{pH}$ buffered to match the exposure waters $(\mathrm{pH} 5$ or $\mathrm{pH} 7)$. Fish were measured for length and weight and then whole blood was collected via caudal puncture into lithium heparinised syringes. Haematocrit (Hct) was calculated in duplicate by centrifuging whole blood in microhaematocrit tubes $(13,000 \mathrm{rpm}, 2 \mathrm{~min}$, Heraeus pico 17 microcentrifuge) and calculating the ratio of packed red cells to supernatant by using a Hawksley reader (Hawksley, Sussex, UK). The haemoglobin (Hb) concentration was calculated by diluting $20 \mu \mathrm{l}$ whole blood in $5 \mathrm{ml}$ of Drabkin's reagent (Sigma-Aldrich, UK) and comparing to cyanmethemoglobin standards at $540 \mathrm{~nm}$. A further $20 \mu \mathrm{l}$ of whole blood was also fixed in $0.98 \mathrm{ml}$ of Dacie's fluid $(10 \mathrm{ml}$ of $40 \%$ formaldehyde, $31.3 \mathrm{~g}$ trisodium citrate, $1.0 \mathrm{~g}$ brilliant crystal blue, diluted to 1 litre with Milli-Q water) for red and white blood cell counts. The remaining blood was centrifuged $(13,000 \mathrm{rpm}$ for 2 min, Micro Centaur MSE), and plasma collected and stored at $-80^{\circ} \mathrm{C}$ until subsequent analysis of plasma ions and osmometry. Plasma $\mathrm{Na}^{+}$and $\mathrm{K}^{+}$were analysed by flame photometry (Corning 420 Flame photometer), while plasma chloride was analysed by automated titration (Jenway PCLM 3Chloride Meter). Osmotic pressure was determined by the freezing-point depression method using $50 \mu$ l of plasma (Precision System micro osmometer, Natick, Massachusetts, USA).

\subsection{Tissue ion analysis}

Following blood sampling, fish were dissected for tissue metal analysis. Gill, liver, spleen and kidney were harvested and washed with Milli-Q water and processed for ion analysis according to Handy et al. (2000) with minor modification. Samples were placed on clean glass slides and dried to constant weight (Gallenkamp Oven BS Model OV-160) at $100^{\circ} \mathrm{C}$ for $48 \mathrm{~h}$, then the dried tissue was removed into polypropylene scintillation vials (VWR International Ltd., Poole, UK). Samples (typically 0.1-0.5 g dried tissue) were digested in $4 \mathrm{ml}$ of concentrated nitric acid (analytical grade, Fisher Scientific, UK) at $70^{\circ} \mathrm{C}$ for $3 \mathrm{~h}$ in a water bath, allowed to cool, then diluted to $16 \mathrm{ml}$ with ultra pure water (Milli-Q). For very small tissue samples (less than $0.1 \mathrm{~g}$ dry weight) the volumes of reagents were reduced to $1 \mathrm{ml}$ of nitric acid and then diluted to a final volume of $4 \mathrm{ml}$ with Milli-Q water. Samples were then analysed for trace elements (e.g. $\mathrm{Cu}, \mathrm{Ca}, \mathrm{Na}, \mathrm{K}, \mathrm{Mn}$ and $\mathrm{Zn}$ ) by ICP-OES And compared with matrix-matched standards prepared from Aristar ${ }^{\circledR}$ plasma emission grade solutions, with accuracy checked after every 10 samples during the analysis by running a blank or standard as a sample. Spike recovery tests were performed with both $\mathrm{CuSO}_{4}$ and $\mathrm{Cu}-\mathrm{NPs}$ using rainbow trout gill and liver digested as above and were (\% mean \pm S.E.M, $n=6): 94 \pm 1(\mathrm{Cu}-\mathrm{NPs})$ and $102 \pm 1\left(\mathrm{CuSO}_{4}\right)$ in the gill tissues and $92 \pm 2$ (Cu-NPs) and $102 \pm 1\left(\mathrm{CuSO}_{4}\right)$ in the liver.

\subsection{Biochemistry}

Additional fish at days 0,4 and 7 ( $n=6$ fish/treatment and initial fish) were euthanized as described in Section 2.4 and tissues (gill, liver, kidney, and spleen) were harvested and immediately snap frozen in liquid nitrogen and stored at $-80^{\circ} \mathrm{C}$ until required. Tissues (approximately $0.5 \mathrm{~g}$ ) were weighed and homogenised $(3 \times 10$ s with 2 min rest at $17,500 \mathrm{rpm}$, Cat X520D with a T6 shaft, medium speed, Bennett \& Co., Weston-super-Mare) in five volumes of ice-cold isotonic buffer solution (in mmoll ${ }^{-1} ; 300$ sucrose, 0.1 ethylenediamine tetra acetic acid (EDTA), 20 HEPES [4-(2-hydroxyethyl) piperazine-1-ethane sulfonic acid], adjusted to $\mathrm{pH} 7.8$ with a few drops of Tris (2-amino-2-hydroxyl-1,3propanediol)). Crude homogenates were centrifuged for $2 \mathrm{~min}$ $\left(13,000 \mathrm{rpm}\right.$ at $\left.4^{\circ} \mathrm{C}\right)$ after which the supernatant was stored in $0.5 \mathrm{ml}$ aliquots at $-80^{\circ} \mathrm{C}$ until required. Tissue homogenates were analysed exactly as described in Smith et al. (2007) in triplicate wells per sample for $\mathrm{Na}^{+} / \mathrm{K}^{+}$-ATPase activity $(15 \mu \mathrm{l}$ of homogenate), thiobarbituric acid reactive substances (TBARS, $40 \mu \mathrm{l}$ of homogenate), and total glutathione (GSH, $20 \mu$ l of homogenate).

\subsection{Statistical analysis}

The resulting data were analysed by SigmaPlot version 13.0 (Systat Software, Inc.) and StatGraphics Plus version 5.1 (StatPoint Technologies, Inc.). Throughout the experiment, no tank effects were seen, so data were pooled according to treatment for statistical analyses. Briefly, normally-distributed data (Shapiro-Wilk test, $\log _{10}$ transformed if required) that had equal variances (Brown-Forsythe test) were analysed according to independent variables treatment, $\mathrm{pH}$, time, and their interactions by a 3-way ANOVA with Fisher's LSD test post hoc. Where the main effects could not be interpreted due to interactions between variables, and to detect simple effects, one-way ANOVA and a Fisher's LSD test post hoc was used. If data were not normally distributed and transformation failed, the Kruskal-Wallis test was used. Data are presented as means \pm S.E.M. All statistical analyses used a probability level of $0.05(p<0.05)$ to reject the null hypothesis.

\section{Results}

\subsection{Total Cu concentrations in water and tissues}

Water samples taken within 10 min of dosing of experimental tanks confirmed exposures of fish to $\mathrm{Cu}$. The total $\mathrm{Cu}$ concentrations in tanks were: $2.94 \pm 0.05,20.36 \pm 0.27,19.42 \pm 0.12 \mu \mathrm{gl}^{-1}$ at $\mathrm{pH} 7$ and $3.23 \pm 0.12,20.53 \pm 0.08,19.62 \pm 0.21 \mu \mathrm{gl}^{-1}$ at pH 5 (for the control, $20 \mu \mathrm{gl}^{-1}$ of either $\mathrm{Cu}$ as $\mathrm{CuSO}_{4}$ or $\mathrm{Cu}-\mathrm{NPs}$ treatments respectively, $n=12$ ), representing recoveries of $97-103 \%$ of nominal concentrations of $\mathrm{CuSO}_{4}$ and $\mathrm{Cu}-\mathrm{NPs}$. At the end of the $12 \mathrm{~h}$ exposure period between water changes measurable $\mathrm{Cu}$ concentrations in tanks had decreased in all treatments and were 85.7 and $77.7 \%$ at pH 7 and 88.6 and $83.8 \%$ at pH 5 for $\mathrm{CuSO}_{4}$ and $\mathrm{Cu}-\mathrm{NPs}$ treatments, respectively.

Dialysis experiments with $\mathrm{Cu}-\mathrm{NPs}$ in Plymouth tap water were conducted at $\mathrm{pH} 7$ and 5 (Fig. 2). The $\mathrm{Cu}-\mathrm{NPs}$ at $\mathrm{pH} 7$ rapidly reached equilibrium, with a maximum total Cu-NP dissolution of $7.5 \pm 0.8 \%$. However, for $\mathrm{Cu}-\mathrm{NPs}$ at pH 5, no equilibrium was reached with a steady increase in dissolution of $\mathrm{Cu}$ across all time-points measured reaching a maximum of $20.9 \pm 3.9 \%$ NP dissolution at $24 \mathrm{~h}$. Concentrations of $\mathrm{Cu}$ in control beakers were unchanged over the $24 \mathrm{~h}$ period and were consistently below the limit of detection of this analysis run $\left(<0.0083 \mathrm{mg} \mathrm{l}^{-1}\right)$.

The exposures were also confirmed by measuring total $\mathrm{Cu}$ concentrations in the tissues of fish (Fig. 3). A three-way ANOVA with 


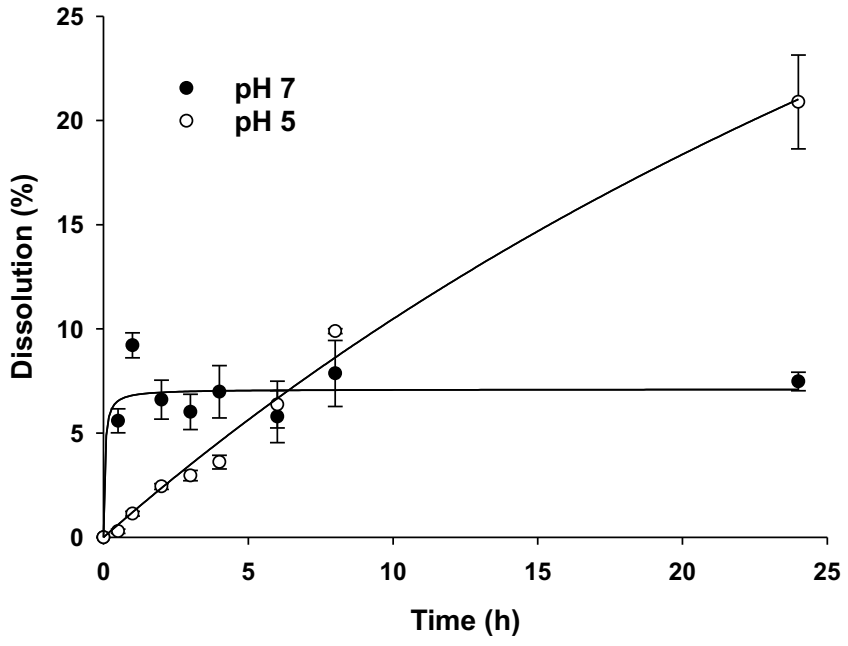

Fig. 2. Dissolution of Cu-NPs (\% of measured total $\mathrm{Cu}$ ) in dechlorinated Plymouth tap water adjusted to $\mathrm{pH} 7$ (closed symbols) and 5 (open symbols) over $24 \mathrm{~h}$. Data are means \pm S.E.M, $n=3$ replicates. Curves for dissolved $\mathrm{Cu}$ concentration were fitted by using a rectangular hyperbole function (one site, ligand binding to saturation) in SigmaPlot $v$. 13. The Cu concentrations in controls (no Cu-NPs, dialysis tubing only) were below the instrument detection limits and are not shown.

treatment, $\mathrm{pH}$ and day as between-subjects factors revealed main effects of treatment $\left(F_{2,60}=69.8, p<0.001\right)$ and $\mathrm{pH}\left(F_{1,60}=8.79\right.$, $p=0.004)$ on $\mathrm{Cu}$ accumulation in gills of fish. All other main effects and interactions were non-significant. Copper accumulation was observed in the gills of trout exposed to both $\mathrm{CuSO}_{4}$ and $\mathrm{Cu}-\mathrm{NPs}$ treatments, on both days 4 and 7 and also at both $\mathrm{pH} 7$ and 5 . Post hoc tests with the Fisher's LSD test indicated that $\mathrm{Cu}$ accumulation was greater in fish exposed to $\mathrm{CuSO}_{4}$ than $\mathrm{Cu}-\mathrm{NPs}$ i.e. a nano-effect $(p<0.001)$. A pH effect was observed for branchial $\mathrm{Cu}$ accumulation in fish exposed to $\mathrm{CuSO}_{4}$ which showed significantly less accumulation of $\mathrm{Cu}$ at $\mathrm{pH} 5$ compared to $\mathrm{pH} 7$ (Fisher's LSD test, $p=0.004)$. Nano copper-treated fish did not show any pH effects.
There was also a main effect of treatment $\left(F_{2,60}=7.97, p<0.001\right)$ on $\mathrm{Cu}$ accumulation in livers of fish. Post hoc tests indicated higher $\mathrm{Cu}$ concentrations in livers of fish exposed to $\mathrm{CuSO}_{4}(p<0.001)$ and $\mathrm{Cu}-\mathrm{NPs}(p=0.033)$ compared to controls, but no evidence of a nanoeffect $(p=0.075)$. Copper concentrations were lower in spleens of fish at $\mathrm{pH} 5$ than $\mathrm{pH} 7\left(F_{1,60}=19.1, p<0.001\right)$ but there were no effects of treatment (or day or interactions). Although, there were some effects of exposure time and $\mathrm{pH}$ on $\mathrm{Cu}$ accumulation in the kidney, there were no clear patterns of treatment related effects on $\mathrm{Cu}$ concentrations in the kidney.

\subsection{Haematology and blood plasma analyses}

Exposure of trout to $\mathrm{Cu}$ as $\mathrm{CuSO}_{4}$ or $\mathrm{Cu}-\mathrm{NPs}$ at neutral and acidic $\mathrm{pH}$ values caused changes in some blood parameters (Table 1 ). The main effects of treatment, day and $\mathrm{pH}$ on $\mathrm{Hb}$ concentrations, Hct values, as well as red and white blood cell counts could not be fully interpreted with 3-way ANOVA due to multiple significant interactions that were detected between factors; however, post hoc Fisher's LSD test and one-way ANOVA provided additional resolution. There was an effect of treatment on Hb concentrations (3-way ANOVA, $F_{2,60}=3.35, p=0.042$ ) that was qualified by an interaction between treatment and day $\left(F_{2,60}=5.42, p=0.007\right)$ and treatment and $\mathrm{pH}\left(F_{2,60}=14.0, p<0.001\right)$. At $\mathrm{pH} 7$ and at day 4 , Hb concentrations were lower in fish exposed to $\mathrm{CuSO}_{4}$ compared to both controls and $\mathrm{Cu}-\mathrm{NPs}$ (one-way ANOVA, $p<0.05$ ). These had partially recovered by day 7 . An opposite effect of treatment on Hb concentrations was evident on day 7 at lower $\mathrm{pH}$ with elevations observed in fish exposed to both $\mathrm{CuSO}_{4}$ and $\mathrm{Cu}-\mathrm{NPs}$ compared to controls (one-way ANOVA, $p<0.05$ ). Similar trends were also apparent in Hct and red blood cell counts. A 3-way ANOVA indicated greater Hct in fish at $\mathrm{pH} 5$ compared to $\mathrm{pH} 7\left(F_{1,60}=23.9, p<0.001\right)$ that was qualified by a three-way interaction between treatment, day and $\mathrm{pH}\left(F_{2,60}=6.58, p=0.003\right)$. Differences were detected with Fisher's LSD tests and indicated decreased Hct in fish exposed to $\mathrm{CuSO}_{4}$ compared to both controls $(p=0.003)$ and fish exposed to $\mathrm{Cu}-\mathrm{NPs}$ $(p=0.001)$ at day 4 and $\mathrm{pH} 7$; however, Hct had increased (i.e. recov-
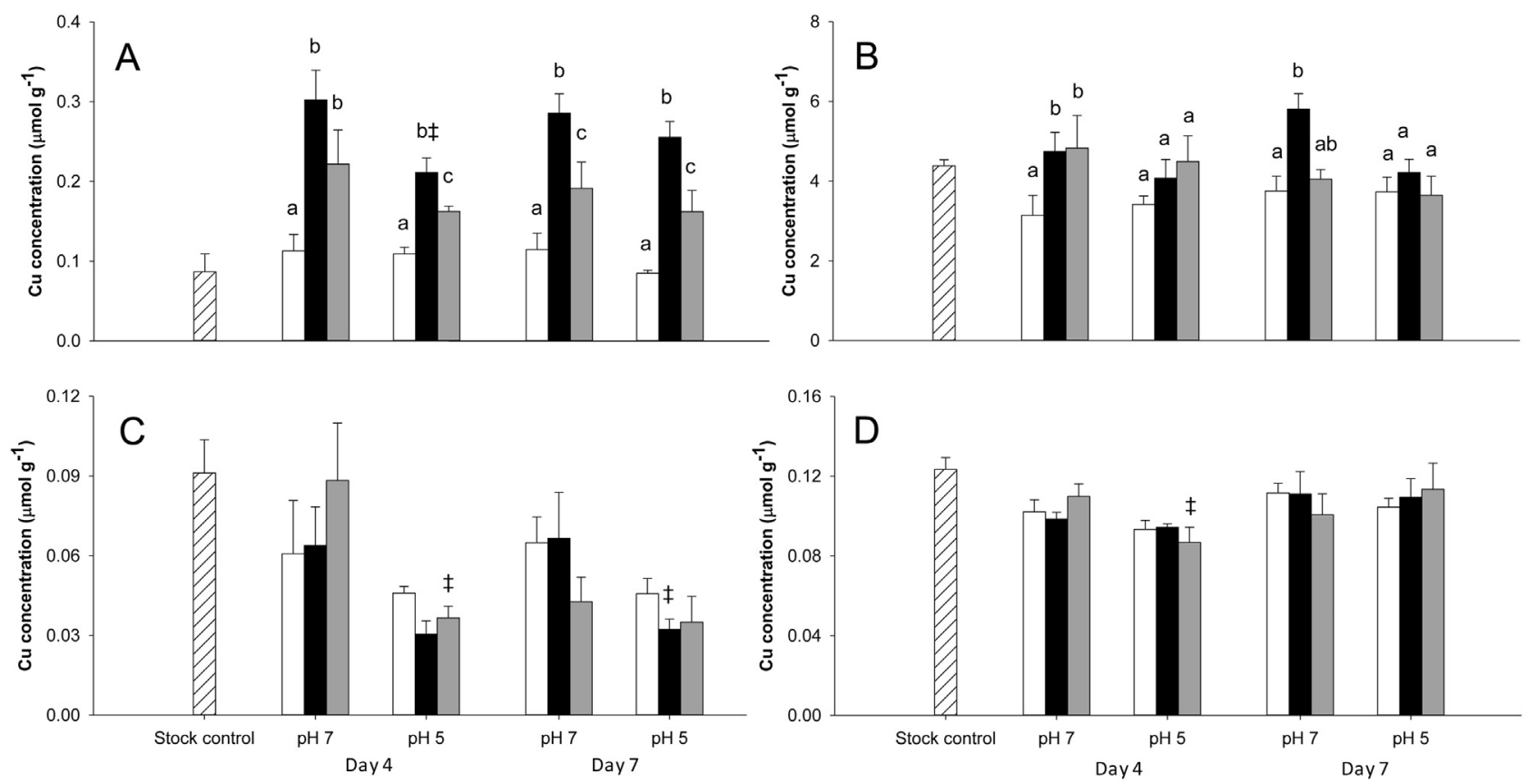

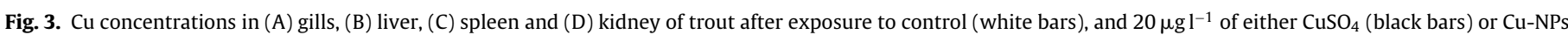

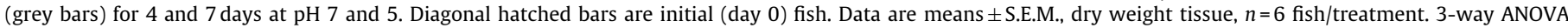

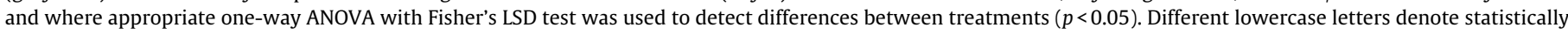

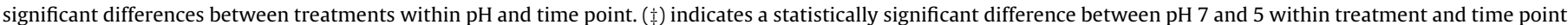


Table 1

Haematology and plasma ions in rainbow trout exposed to control (no added $\mathrm{Cu}$ ), and $20 \mu \mathrm{g} \mathrm{l} \mathrm{l}^{-1}$ of either $\mathrm{CuSO} \mathrm{Or}_{\mathrm{Cu}} \mathrm{NPs}$ at $\mathrm{pH} 7$ and 5.

\begin{tabular}{|c|c|c|c|c|c|c|c|c|}
\hline \multirow[t]{2}{*}{ Parameter } & \multirow[t]{2}{*}{ Day 0 fish } & \multirow[t]{2}{*}{ Day } & \multicolumn{3}{|l|}{$\mathrm{pH} 7$} & \multicolumn{3}{|l|}{ pH 5} \\
\hline & & & Control & $\mathrm{CuSO}_{4}$ & Cu-NPs & Control & $\mathrm{CuSO}_{4}$ & Cu-NPs \\
\hline Haemoglobin $\left(\mathrm{mg} \mathrm{dl}^{-1}\right)$ & $17.4 \pm 0.5$ & $\begin{array}{l}4 \\
7\end{array}$ & $\begin{array}{l}19.8 \pm 0.8^{\mathrm{a}} \\
19.3 \pm 1.0\end{array}$ & $\begin{array}{l}13.9 \pm 0.5^{b} \\
16.9 \pm 0.9^{+}\end{array}$ & $\begin{array}{l}18.8 \pm 0.7^{\mathrm{a}} \\
16.9 \pm 1.2\end{array}$ & $\begin{array}{l}16.6 \pm 1.0 \\
14.9 \pm 1.2^{\mathrm{a}}\end{array}$ & $\begin{array}{l}17.7 \pm 0.9 \\
19.0 \pm 0.9^{b}\end{array}$ & $\begin{array}{l}20.5 \pm 1.5 \\
18.5 \pm 0.9^{b}\end{array}$ \\
\hline Haematocrit (\%) & $20.3 \pm 0.8$ & $\begin{array}{l}4 \\
7\end{array}$ & $\begin{array}{l}23.3 \pm 1.0^{\mathrm{a}} \\
23.2 \pm 1.3\end{array}$ & $\begin{array}{l}19.0 \pm 0.4^{b} \\
25.7 \pm 0.5^{+}\end{array}$ & $\begin{array}{l}23.7 \pm 0.7^{\mathrm{a}} \\
21.2 \pm 0.9\end{array}$ & $\begin{array}{l}26.3 \pm 1.0 \\
24.7 \pm 1.7\end{array}$ & $\begin{array}{l}27.7 \pm 1.2 \\
25.7 \pm 1.5\end{array}$ & $\begin{array}{l}25.5 \pm 0.3 \\
25.2 \pm 1.8\end{array}$ \\
\hline Red blood cells $\left(\times 10^{6}\right)$ & $0.57 \pm 0.00$ & $\begin{array}{l}4 \\
7\end{array}$ & $\begin{array}{l}0.71 \pm 0.04^{\mathrm{a}} \\
0.72 \pm 0.01^{\mathrm{a}}\end{array}$ & $\begin{array}{l}0.54 \pm 0.01^{\mathrm{b}} \\
0.63 \pm 0.01^{\mathrm{b}+}\end{array}$ & $\begin{array}{l}0.60 \pm 0.01^{b} \\
0.62 \pm 0.14^{b}\end{array}$ & $\begin{array}{l}0.73 \pm 0.02 \\
0.57 \pm 0.04^{\ddagger}\end{array}$ & $\begin{array}{l}0.65 \pm 0.03^{\ddagger} \\
0.69 \pm 0.05\end{array}$ & $\begin{array}{l}0.68 \pm 0.05 \\
0.67 \pm 0.04\end{array}$ \\
\hline White blood cells $\left(\times 10^{3}\right)$ & $15.6 \pm 0.8$ & $\begin{array}{l}4 \\
7\end{array}$ & $\begin{array}{l}18.3 \pm 1.9 \\
13.0 \pm 0.2^{\mathrm{a} \ddagger}\end{array}$ & $\begin{array}{l}17.3 \pm 0.7 \\
17.2 \pm 0.8^{b}\end{array}$ & $\begin{array}{l}15.8 \pm 1.0 \\
15.5 \pm 0.5^{\mathrm{ab}}\end{array}$ & $\begin{aligned} 25.3 & \pm 3.4^{\mathrm{a} \ddagger} \\
28.51 & \pm 2.1^{\mathrm{a} \ddagger}\end{aligned}$ & $\begin{array}{l}17.2 \pm 0.72^{\mathrm{b}} \\
35.0 \pm 2.7^{\mathrm{b}+\ddagger}\end{array}$ & $\begin{array}{l}22.2 \pm 2.5^{\mathrm{a} \ddagger} \\
34.7 \pm 0.8^{\mathrm{b}+}\end{array}$ \\
\hline Plasma $\mathrm{Na}^{+}\left(\mathrm{mmoll}^{-1}\right)$ & $155.0 \pm 0.5$ & $\begin{array}{l}4 \\
7\end{array}$ & $\begin{array}{l}148.8 \pm 1.7^{\mathrm{a}} \\
151.6 \pm 2.6^{\mathrm{a}}\end{array}$ & $\begin{array}{l}137.9 \pm 1.6^{\mathrm{b}} \\
130.0 \pm 2.4^{\mathrm{b}}\end{array}$ & $\begin{array}{l}135.4 \pm 1.7^{b} \\
142.5 \pm 4.5^{c}\end{array}$ & $\begin{array}{l}139.9 \pm 2.9^{\ddagger} \\
126.7 \pm 1.6^{+\ddagger}\end{array}$ & $\begin{array}{l}133.6 \pm 0.6 \\
126.6 \pm 1.1^{+}\end{array}$ & $\begin{array}{l}133.1 \pm 1.9 \\
126.9 \pm 2.9^{+\ddagger}\end{array}$ \\
\hline Plasma K+ $\left(\mathrm{mmoll}^{-1}\right)$ & $3.03 \pm 0.01$ & $\begin{array}{l}4 \\
7\end{array}$ & $\begin{array}{l}2.89 \pm 0.05^{\mathrm{a}} \\
3.00 \pm 0.01^{\mathrm{a}}\end{array}$ & $\begin{array}{l}2.52 \pm 0.08^{\mathrm{b}} \\
2.82 \pm 0.09^{\mathrm{ab}+}\end{array}$ & $\begin{array}{l}2.49 \pm 0.03^{\mathrm{b}} \\
2.73 \pm 0.09^{\mathrm{b}+}\end{array}$ & $\begin{array}{l}2.66 \pm 0.18^{a} \\
3.66 \pm 0.18^{+\ddagger}\end{array}$ & $\begin{array}{l}2.86 \pm 0.14^{\mathrm{a}} \\
3.69 \pm 0.27^{+\ddagger}\end{array}$ & $\begin{array}{l}3.35 \pm 0.17^{b \ddagger} \\
3.34 \pm 0.06^{\ddagger}\end{array}$ \\
\hline Plasma Cl- $\left(\mathrm{mmoll}^{-1}\right)$ & $160.3 \pm 1.9$ & $\begin{array}{l}4 \\
7\end{array}$ & $\begin{array}{l}154.3 \pm 3.2 \\
158.1 \pm 2.7^{\mathrm{ab}}\end{array}$ & $\begin{array}{l}151.4 \pm 0.5 \\
157.4 \pm 2.9^{\mathrm{a}}\end{array}$ & $\begin{array}{l}157.3 \pm 2.0 \\
150.7 \pm 2.6^{b}\end{array}$ & $\begin{array}{l}146.8 \pm 4.4 \\
142.9 \pm 3.0\end{array}$ & $\begin{array}{l}138.5 \pm 5.4^{\ddagger} \\
147.7 \pm 2.6^{+\ddagger}\end{array}$ & $\begin{array}{l}145.8 \pm 1.3^{\ddagger} \\
145.9 \pm 2.2\end{array}$ \\
\hline
\end{tabular}

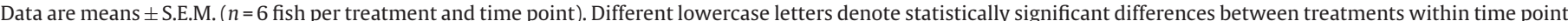

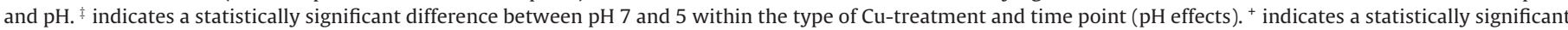

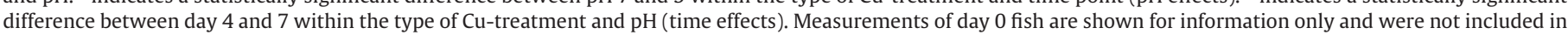
statistical analyses. Data were analysed with 3-way ANOVA and where appropriate one-way ANOVA with Fisher's LSD test ( $p<0.05$ ).

ered) by day 7 ( $p<0.001)$. Red blood cell counts were similarly diminished in fish exposed to both $\mathrm{CuSO}_{4}$ and $\mathrm{Cu}-\mathrm{NPs}$ compared to controls at pH 7 and on both days 4 and 7 (one-way ANOVAs, $p<0.05$ ). Exposure to low $\mathrm{pH}$ had a pronounced effect on white blood cell counts (elevated, 3-way ANOVA, $F_{1,60}=131.6, p<0.001$ ) which changed with the duration of exposure (increased by day $\left.7, F_{1,60}=15.5, p<0.001\right)$ but these were qualified by an interaction between these two factors $\left(F_{1,60}=42.1, p<0.001\right)$. Exposure to $\mathrm{Cu}$ also affected white blood cell counts. Specifically, counts were lower in fish exposed to $\mathrm{CuSO}_{4}$ and $\mathrm{Cu}$-NPs compared to controls at day 4 , but the effect was reversed by day 7 (one way ANOVAs, $p<0.05$ ).

Blood plasma electrolytes showed $\mathrm{pH}$, treatment and time effects (Table 1). Plasma $\mathrm{Na}^{+}$was affected by treatment $\left(F_{2,60}=17.8\right.$, $p<0.001)$, day $\left(F_{1,60}=10.6, p=0.002\right)$ and $\mathrm{pH}\left(F_{1,60}=53.3, p<0.001\right)$ although these effects were qualified by a 3-way interaction between factors $\left(F_{2,60}=3.85, p=0.027\right)$. At $\mathrm{pH} 7$ both $\mathrm{CuSO}_{4}$ and $\mathrm{Cu}-\mathrm{NPs}$ exposed fish showed depleted $\mathrm{Na}^{+}$compared to controls on day 4 (Fisher's LSD tests, $p=0.002$ and $p<0.001$, respectively). By day 7 a similar decrease in plasma $\mathrm{Na}^{+}$of fish exposed to $\mathrm{CuSO}_{4}$ and $\mathrm{Cu}-\mathrm{NPs}$ was also evident and there was evidence of a nanoeffect (worse with $\mathrm{CuSO}_{4}$ ). In fish exposed at $\mathrm{pH} \mathrm{5}$, plasma $\mathrm{Na}^{+}$ was observed to decrease from day 4 to day 7 across all treatments (Fisher's LSD test, $p<0.001$, one-way ANOVA $p<0.05$ ). The interpretation of effects of $\mathrm{Cu}$ exposures on plasma $\mathrm{K}^{+}$concentrations were complicated by a 3-way interaction between treatment, day and $\mathrm{pH}$ (3-way ANOVA, $F_{2,60}=5.23, p=0.008$ ). Although values remained largely in the normal range, there were a few small, but statistically significant changes. These included a decrease in the $\mathrm{K}^{+}$of both the $\mathrm{CuSO}_{4}$ and $\mathrm{Cu}-\mathrm{NP}$ treatments at $\mathrm{pH} 7$ compared to the control (Fisher's LSD tests $p=0.017$ and $p=0.005$, respectively). There was also a large elevation in plasma $\mathrm{K}^{+}$in $\mathrm{Cu}-\mathrm{NPs}$ exposed fish at pH 5 on day 4 compared to controls and also fish exposed to $\mathrm{CuSO}_{4}$ (Fisher's LSD tests, $p<0.001$ and $p=0.01$, respectively). Overall, there was also a small $\mathrm{pH}$-effect on plasma $\mathrm{K}^{+}$concentration, with slightly elevated values at $\mathrm{pH} 5$ compared to $\mathrm{pH} 7$, in both the $\mathrm{CuSO}_{4}$ and $\mathrm{Cu}-\mathrm{NPs}$ treatments (ANOVA, $p<0.05$ ). Plasma $\mathrm{Cl}^{-}$concentrations also remained in the normal range, but with a few small, differences that were inconsistent over time. There was a $\mathrm{pH}$-effect on plasma $\mathrm{Cl}^{-}$concentration (3-way ANOVA, $F_{1,60}=34.5$, $p<0.001$ ), with all treatments showing lower plasma $\mathrm{Cl}^{-}$concen- tration at pH 5 compared to $\mathrm{pH}$ 7. There was no Cu-treatment or pH-effects on plasma osmolarity (data not shown).

\subsection{Tissue electrolytes}

There were some differences in the electrolyte concentrations in some of the tissues of trout during exposures to $\mathrm{CuSO}_{4}$ or Cu-NPs, and at each pH value (Table 2). However, many of the changes were transient with no clear treatment or time-dependent trend. In the gill tissue, there were effects of treatment (3-way ANOVA, $\left.F_{2,60}=5.881, p=0.005\right)$, day $\left(F_{1,60}=12.3, p<0.001\right)$ and $\mathrm{pH}$ $\left(F_{1,60}=36.6, p<0.001\right)$ although these were partially qualified by an interaction between treatment and day $\left(F_{2,60}=3.37, p=0.041\right)$. Post hoc Fisher's LSD test indicated elevated $\mathrm{Na}^{+}$concentrations in $\mathrm{CuSO}_{4}$ treated fish compared to controls $(p<0.001)$ and $\mathrm{Cu}-\mathrm{NPs}$ treated fish (a nano effect, $p=0.003$ ) at day 4 and simple effects were further investigated with one-way ANOVA (see annotations in Table 2). Exposure to acid caused some branchial $\mathrm{Na}^{+}$depletion that was also evident in the $\mathrm{pH} 5 / \mathrm{CuSO}_{4}$ and the $\mathrm{pH} 5 / \mathrm{Cu}-\mathrm{NP}$ treatments (one-way ANOVA, $p<0.05$ ), but with no material-type effect by the end of the experiment. There were also effects of treatment (3-way ANOVA, $\left.F_{2,60}=4.32, p=0.018\right)$ and day $\left(F_{1,60}=7.25, p=0.009\right)$ on branchial $\mathrm{K}^{+}$concentrations. At low $\mathrm{pH}$, branchial $\mathrm{K}^{+}$concentrations showed an increase in fish from the $\mathrm{CuSO}_{4}$ and $\mathrm{Cu}-\mathrm{NP}$ treatments compared to the control (one-way ANOVA, $p<0.05$ ), but there was no $\mathrm{pH}$-effect between materials. Branchial $\mathrm{Zn}$ concentrations were affected by $\mathrm{pH}$ of the water (3-way ANOVA, $F_{1,60}=16.3, p<0.001$ ), but there were no main effects of treatment or day of exposure.

Hepatic $\mathrm{Na}^{+}$showed a $\mathrm{pH}$-effect which included a decrease in the $\mathrm{Na}^{+}$concentration in livers of fish from both $\mathrm{CuSO}_{4}$ and $\mathrm{Cu}-$ $\mathrm{NP}$ treatment at $\mathrm{pH} 5$ when compared to $\mathrm{pH} 7$ (3-way ANOVA, $F_{1,60}=23.1, p<0.001$, one-way ANOVA $p<0.05$, Table 2). Hepatic $\mathrm{Na}^{+}$concentrations did not show Cu-treatment or time effects, except for a small material-type effect with a decrease in $\mathrm{Na}^{+}$ concentration in the Cu-NP treatment compared to the $\mathrm{CuSO}_{4}$ treatment at pH 5 (3-way ANOVA, $F_{2,60}=4.91, p<0.001$, one-way ANOVA, $p<0.05)$. There were some small, transient decreases in hepatic $\mathrm{K}^{+}$concentrations in both the $\mathrm{CuSO}_{4}$ and $\mathrm{Cu}-\mathrm{NP}$ treatment at $\mathrm{pH} 7$ on day 4 compared to controls (3-way ANOVA, significant interaction between treatment, time and $\mathrm{pH}, F_{2,60}=4.58$, $p=0.014$, post hoc Fisher's LSD tests between treatments, $p<0.001$ 
Table 2

Electrolyte concentrations ( $\mu \mathrm{mol} \mathrm{g}^{-1}$ dry weight) in the gill and liver of rainbow exposed to control (no added $\mathrm{Cu}$ ), and $20 \mu \mathrm{gl} \mathrm{l}^{-1}$ of either $\mathrm{CuSO}{ }_{4}$ or $\mathrm{Cu}-\mathrm{NPs}$ at $\mathrm{pH} 7$ and 5 .

\begin{tabular}{|c|c|c|c|c|c|c|c|c|c|}
\hline \multirow[t]{2}{*}{ Tissue } & \multirow[t]{2}{*}{ Tissue } & \multirow[t]{2}{*}{ Day 0 fish } & \multirow[t]{2}{*}{ Day } & \multicolumn{3}{|l|}{$\mathrm{pH} 7$} & \multicolumn{3}{|l|}{ pH 5} \\
\hline & & & & Control & $\mathrm{CuSO}_{4}$ & Cu-NPs & Control & $\mathrm{CuSO}_{4}$ & Cu-NPs \\
\hline \multirow[t]{8}{*}{ Gill } & $\mathrm{Na}$ & $231.6 \pm 9.1$ & 4 & $196.3 \pm 7.5^{\mathrm{a}}$ & $249.4 \pm 5.9^{b}$ & $214.6 \pm 7.8^{\mathrm{a}}$ & $183.1 \pm 10.8$ & $200.3 \pm 10.0^{\ddagger}$ & $180.9 \pm 14.3^{\ddagger}$ \\
\hline & & & 7 & $232.2 \pm 10.2^{+}$ & $245.2 \pm 3.1$ & $241.4 \pm 6.7^{+}$ & $196.2 \pm 4.1^{\ddagger}$ & $209.0 \pm 8.2^{\ddagger}$ & $211.5 \pm 6.6^{\ddagger+}$ \\
\hline & K & $385.4 \pm 4.8$ & 4 & $372.4 \pm 2.9$ & $379.2 \pm 8.9$ & $388.6 \pm 9.0$ & $376.5 \pm 12.2$ & $390.8 \pm 6.9$ & $371.5 \pm 8.4$ \\
\hline & & & 7 & $391.9 \pm 5.5^{\mathrm{a}}$ & $409.8 \pm 9.6^{\mathrm{ab}+}$ & $418.1 \pm 7.5^{\mathrm{b}+}$ & $365.8 \pm 3.5^{\mathrm{a}}$ & $409.3 \pm 3.4^{b}$ & $408.6 \pm 4.0^{\mathrm{b}+}$ \\
\hline & $\mathrm{Ca}$ & $138.0 \pm 12.8$ & 4 & $109.4 \pm 21.0$ & $127.3 \pm 24.7$ & $95.2 \pm 19.6$ & $43.1 \pm 5.9^{\ddagger}$ & $88.8 \pm 22.1$ & $54.5 \pm 10.4$ \\
\hline & & & 7 & $107.7 \pm 23.1$ & $105.7 \pm 25.7$ & $123.3 \pm 23.0$ & $77.7 \pm 16.4$ & $52.6 \pm 8.4$ & $104.8 \pm 22.2$ \\
\hline & $\mathrm{Zn}$ & $5.5 \pm 0.9$ & 4 & $6.7 \pm 0.7$ & $6.3 \pm 1.2$ & $6.1 \pm 1.0$ & $9.7 \pm 2.0$ & $8.6 \pm 2.1$ & $13.1 \pm 2.2^{\ddagger}$ \\
\hline & & & 7 & $9.5 \pm 1.6$ & $2.9 \pm 0.1$ & $4.5 \pm 1.2$ & $9.1 \pm 1.1$ & $10.6 \pm 1.5^{\ddagger}$ & $10.3 \pm 1.5^{\ddagger}$ \\
\hline \multirow[t]{8}{*}{ Liver } & $\mathrm{Na}$ & $76.0 \pm 3.2$ & 4 & $72.6 \pm 3.4$ & $75.1 \pm 2.2$ & $74.1 \pm 1.4$ & $67.4 \pm 1.5^{\mathrm{ab}}$ & $73.1 \pm 1.8^{\mathrm{a}}$ & $63.9 \pm 1.9^{\mathrm{b} \ddagger}$ \\
\hline & & & 7 & $69.5 \pm 0.3$ & $77.4 \pm 0.8$ & $74.2 \pm 5.5$ & $64.8 \pm 3.0$ & $67.9 \pm 2.0^{\ddagger}$ & $64.8 \pm 2.5^{\ddagger}$ \\
\hline & K & $359.8 \pm 14.5$ & 4 & $414.7 \pm 8.8^{\mathrm{a}}$ & $393.5 \pm 5.3^{b}$ & $384.2 \pm 4.9^{\mathrm{b}}$ & $363.6 \pm 4.0^{\ddagger}$ & $362.9 \pm 6.7^{\ddagger}$ & $362.1 \pm 0.7$ \\
\hline & & & 7 & $406.4 \pm 4.0$ & $390.2 \pm 5.6$ & $409.8 \pm 7.6^{+}$ & $369.5 \pm 3.0^{\ddagger}$ & $371.0 \pm 4.3$ & $359.9 \pm 4.3^{\ddagger}$ \\
\hline & $\mathrm{Ca}$ & $4.8 \pm 0.2$ & 4 & $5.2 \pm 0.1^{\mathrm{a}}$ & $5.9 \pm 0.1^{\mathrm{a}}$ & $4.3 \pm 0.1^{\mathrm{b}}$ & $4.8 \pm 0.1$ & $4.1 \pm 0.2^{\ddagger}$ & $4.3 \pm 0.3$ \\
\hline & & & 7 & $5.5 \pm 0.3$ & $5.3 \pm 0.5$ & $5.2 \pm 0.2^{\ddagger}$ & $4.1 \pm 0.2^{\ddagger}$ & $4.2 \pm 0.2^{\ddagger}$ & $4.0 \pm 0.2^{\ddagger}$ \\
\hline & $\mathrm{Zn}$ & $1.3 \pm 0.1$ & 4 & $1.4 \pm 0.1$ & $1.5 \pm 0.0$ & $1.5 \pm 0.1$ & $1.3 \pm 0.1^{\mathrm{a}}$ & $2.1 \pm 0.1^{\mathrm{b} \ddagger}$ & $2.0 \pm 0.1^{\mathrm{b} \ddagger}$ \\
\hline & & & 7 & $1.5 \pm 0.1$ & $1.6 \pm 0.1$ & $1.6 \pm 0.1$ & $2.0 \pm 0.1^{+\ddagger}$ & $2.2 \pm 0.1^{\ddagger}$ & $2.0 \pm 0.1^{\ddagger}$ \\
\hline
\end{tabular}

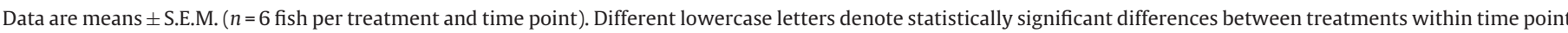

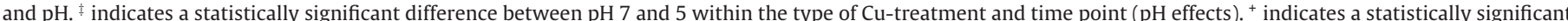

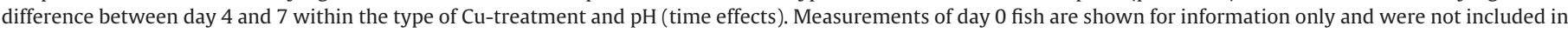
statistical analyses. Data were analysed with 3-way ANOVA and where appropriate one-way ANOVA with Fisher's LSD test $(p<0.05)$

and $p=0.011$, respectively), but no clear material-type effect. Hepatic $\mathrm{Ca}^{2+}$ concentrations were affected by $\mathrm{Cu}$ exposures and $\mathrm{pH}$ (3-way ANOVA, $F_{2,60}=5.45, p=0.007, F_{1,60}=45.7, p<0.001$, respectively). Noteworthy was a small decrease at $\mathrm{pH} 7$ in the $\mathrm{Cu}-\mathrm{NP}$ treatment only, compared to controls and $\mathrm{CuSO}_{4}$ exposed fish (oneway ANOVA, $p<0.05$ ). Effects of $\mathrm{Cu}$ exposures, day of exposure and $\mathrm{pH}$ on hepatic $\mathrm{Zn}$ concentrations were qualified by a 3-way interaction between variables $\left(F_{2,60}=7.57, p<0.001\right)$. Nevertheless, post hoc testing with Fisher's LSD tests indicated increases in hepatic $\mathrm{Zn}$ at day 4 and pH 5 of both Cu treatments and controls (both $p<0.001$ ) but no evidence of a nano effect.

The effects of $\mathrm{CuSO}_{4}$ and $\mathrm{Cu}-\mathrm{NPs}$ on electrolytes in kidney and spleen were minimal. An exception was a pronounced decrease in $\mathrm{K}^{+}$observed in kidney of fish exposed to $\mathrm{CuSO}_{4}$ at $\mathrm{pH} 7$ that was not observed in Cu-NPs exposed fish. Measured concentrations of $\mathrm{K}^{+}$in kidney were: $418.3 \pm 7.8,245.3 \pm 11.6$ and $420.8 \pm 13.0 \mu \mathrm{mol} \mathrm{g}^{-1}$ in control, $\mathrm{CuSO}_{4}$ and Cu-NPs exposed fish, respectively. This effect was not observed in fish exposed to $\mathrm{CuSO}_{4}$ at $\mathrm{pH} 5$ (data not shown).

\section{4. $\mathrm{Na}^{+} / \mathrm{K}^{+}$-ATPase activity}

Exposure to $\mathrm{CuSO}_{4}$ or $\mathrm{Cu}-\mathrm{NPs}$ at $\mathrm{pH} 7$ and 5 caused perturbations in $\mathrm{Na}^{+} / \mathrm{K}^{+}$-ATPase activity in gill of trout (Fig. 4). A 3-way ANOVA revealed main effects of treatment $\left(F_{2,60}=3.73, p=0.030\right)$ and $\mathrm{pH}$ $\left(F_{1,60}=25.0, p<0.001\right)$. This was qualified by interactions between treatment, day and $\mathrm{pH}\left(F_{2,60}=3.99, p=0.024\right)$. At day 4 , the gill of trout exposed to $\mathrm{CuSO}_{4}$ at $\mathrm{pH} 7$ showed an inhibition of $\mathrm{Na}^{+} / \mathrm{K}^{+}$ATPase activity compared to controls (Fisher's LSD test, $p<0.001$ ), with a material-type effect (worse with $\mathrm{CuSO}_{4}$ than $\mathrm{Cu}-\mathrm{NP}$ treatment, Fisher's LSD test, $p=0.002$ ), although activity had returned to control levels, by day 7 (Fisher's LSD test, $p<0.001$ ). At pH 5, exposure to $\mathrm{CuSO}_{4}$ did not cause depletion in the activity of the Na pump although there was a clear trend toward inhibition at day 7 . In kidney, the main effects of treatment, day and $\mathrm{pH}$ on $\mathrm{Na}^{+} / \mathrm{K}^{+}$-ATPase activity could not be interpreted with 3-way ANOVA due to interactions between all factors $\left(F_{2,60}=3.24, p=0.046\right)$. One-way ANOVA indicated elevated $\mathrm{Na}^{+} / \mathrm{K}^{+}$-ATPase activity in fish exposed to $\mathrm{CuSO}_{4}$ and $\mathrm{Cu}-\mathrm{NPs}$ compared to controls at $\mathrm{pH} 5$ on day $4(p<0.05)$, and in fish exposed to $\mathrm{CuSO}_{4}$ compared to controls and fish exposed to $\mathrm{Cu}-\mathrm{NPs}$ i.e. a nano effect at $\mathrm{pH} 7$ on day 7 (Kruskal-Wallis test, $p<0.05$ ).

\subsection{TBARS and total glutathione content}

Trout did not show any Cu-treatment-dependent, or $\mathrm{pH}$ dependent, changes in TBARS in the gill, kidney or spleen (gill, Fig. 5; data not shown for kidney and spleen). In the liver, some small, transient, effects on TBARS were observed. A 3-way ANOVA revealed main effects of treatment $\left(F_{2,60}=5.56, p=0.006\right)$, day $\left(F_{1,60}=15.5, p<0.001\right)$ and $\mathrm{pH}\left(F_{1,60}=7.23, p=0.009\right)$. These main effects were not qualified by interactions between factors. There was lower TBARS in fish exposed to $\mathrm{Cu}-\mathrm{NPs}$ compared to $\mathrm{CuSO}_{4}$ (Fisher's LSD test, $p=0.002$ ) but not compared to controls (Fisher's LSD test, $p=0.053$ ). Specifically, exposure to $\mathrm{Cu}-\mathrm{NPs}$ at $\mathrm{pH} 7$ for 4 days showed a material-type effect (more depletion with $\mathrm{Cu}$ NPs than $\mathrm{CuSO}_{4}$; ANOVA, $p<0.05$ ). At $\mathrm{pH} 5$, there was also a material-type effect on the TBARS value of the $\mathrm{Cu}-\mathrm{NP}$ treatment at day 7 compared to the equivalent $\mathrm{CuSO}_{4}$ treatment (a larger decrease with the $\mathrm{Cu}-\mathrm{NP}$ treatment). There was generally no clear $\mathrm{Cu}$-treatment or pH-effects on the total glutathione (GSH) concentration in the kidney, spleen, or gill over time. In the liver, hepatic GSH concentrations did not show a Cu-treatment effect, but there was a pH-effect which included more depletion at $\mathrm{pH} 5$ with both Cu treatments compared to that at $\mathrm{pH} 7$ (3-way ANOVA, $F_{1,60}=35.1$, $p<0.001$, Fig. 5).

\section{Discussion}

This study is one of the first reports detailing the effects of acidic water on the sub-lethal toxicity and accumulation of $\mathrm{Cu}$ from $\mathrm{Cu}-$ $\mathrm{NP}$ exposure in rainbow trout. In itself, exposure to acid water was observed to cause changes in the ionoregulatory physiology of control fish. Additional effects in trout were also attributable to exposures to $\mathrm{CuSO}_{4}$ and $\mathrm{Cu}-\mathrm{NPs}$. Gill burdens of $\mathrm{Cu}$ increased upon exposure to both $\mathrm{CuSO}_{4}$ and $\mathrm{Cu}-\mathrm{NPs}$, but with greater accumulation from $\mathrm{CuSO}_{4}$ (a material-type effect). Both forms of $\mathrm{Cu}$ also caused perturbations in ion homeostasis, including $\mathrm{Na}^{+}$balance and decreased branchial activity of $\mathrm{Na}^{+} / \mathrm{K}^{+}$-ATPase from exposure to 

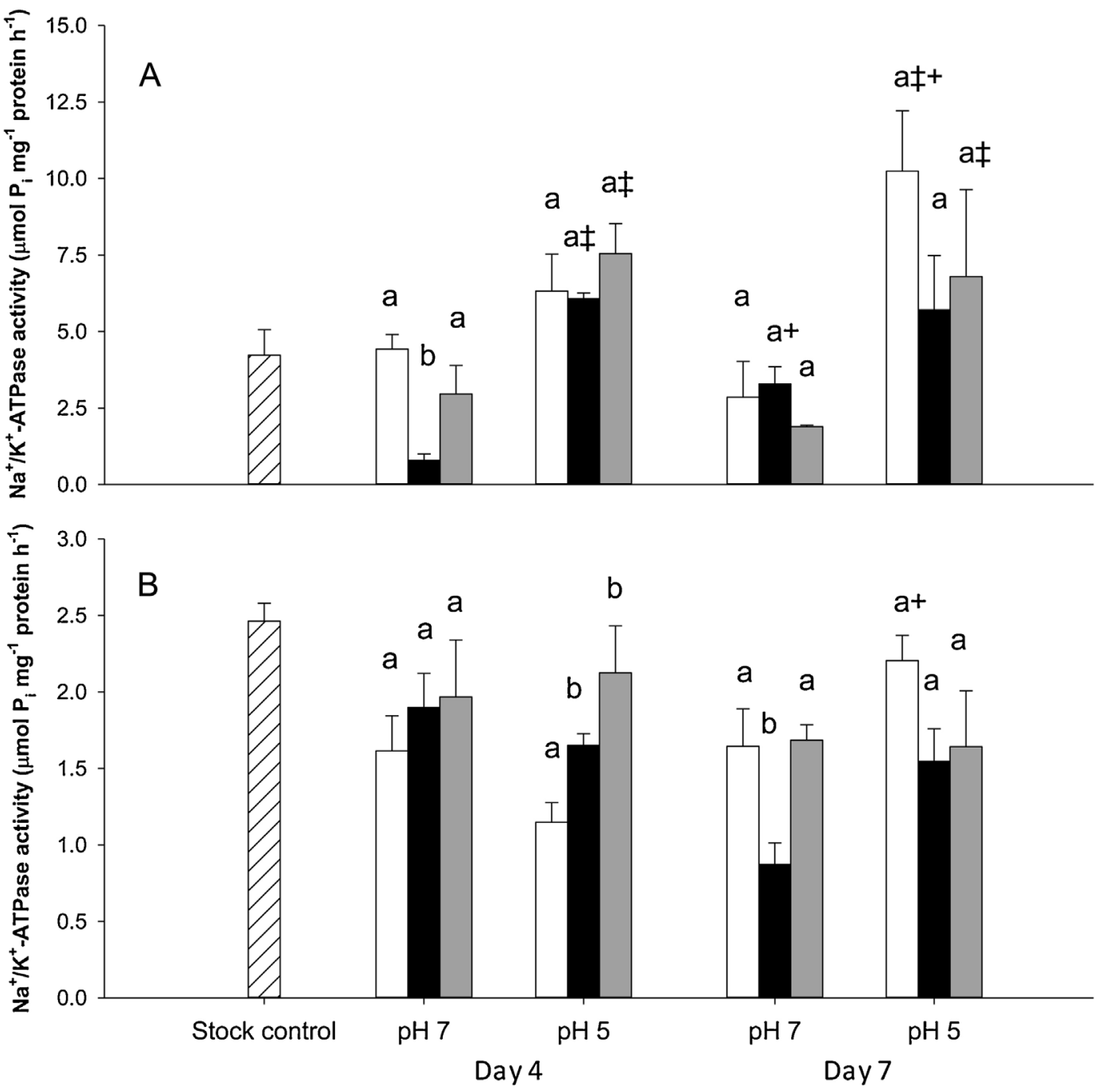

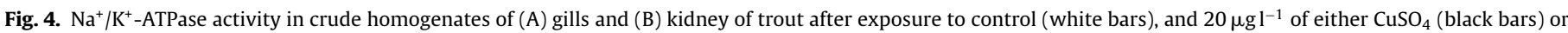

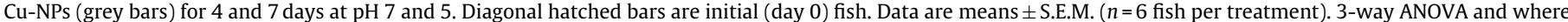

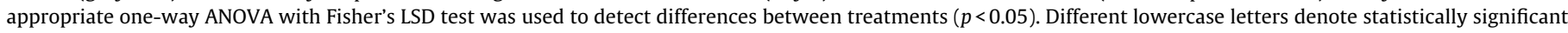

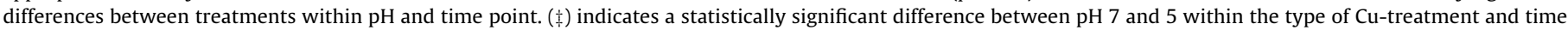
point. (+) indicates a statistically significant difference between day 4 and 7 within the type of $\mathrm{Cu}$-treatment and $\mathrm{pH}$.

$\mathrm{CuSO}_{4}$. In $\mathrm{CuSO}_{4}$-exposed fish, these effects were more pronounced at $\mathrm{pH} 7$ than $\mathrm{pH}$, an effect explained by the decreased bioavailability of dissolved $\mathrm{Cu}$ at the gill under acidic conditions (at day 4). However, gill $\mathrm{Cu}$ accumulation was not significantly lower at $\mathrm{pH} 5$ compared to $\mathrm{pH} 7$ in fish exposed to $\mathrm{Cu}-\mathrm{NPs}$. In acidic water, $\mathrm{Cu}-\mathrm{NPs}$ underwent greater dissolution which may have offset the reduced bioavailability of dissolved $\mathrm{Cu}$. Together, these data indicate that $\mathrm{CuSO}_{4}$ was more toxic to trout than Cu-NPs and the toxicity of the $\mathrm{Cu}-\mathrm{NPs}$ was mediated by the release of the $\mathrm{Cu}$ ion; however, the physico-chemical behaviour of Cu-NPs under variable environmental conditions is an important consideration in risk assessment in freshwaters.

\subsection{Confirming copper exposure and $p H$ effects on $\mathrm{Cu}-\mathrm{NPS}$}

Exposure to $\mathrm{CuSO}_{4}$ and $\mathrm{Cu}-\mathrm{NPs}$ was confirmed by ICP-OES analysis of water samples for total $\mathrm{Cu}$ concentrations, and the measured concentrations were within $3 \%$ of the nominal concentrations. Similar to our previous findings with $\mathrm{CuSO}_{4}$ and $\mathrm{Cu}-\mathrm{NPs}$ (Shaw et al., 2012), the measured total Cu concentrations in the water also suggested that a $12 \mathrm{~h}$ water change was sufficient to maintain the exposure, and would meet likely regulatory test requirements for
NPs (e.g. approximately $80 \%$ or greater of the nominal exposure concentration, Handy et al., 2012). Waterborne exposure to both forms of $\mathrm{Cu}$ at $\mathrm{pH} 7$ and 5 was also confirmed by increases observed in the total $\mathrm{Cu}$ concentrations in/on the gills by ICP-OES (Fig. 3). Irrespective of $\mathrm{pH}$, there was also a material-type effect with higher total $\mathrm{Cu}$ concentrations in the gills of fish exposed to $\mathrm{CuSO}_{4}$ rather than an equal concentration of Cu-NPs. This finding is consistent with our previous experiment on trout where higher total $\mathrm{Cu}$ concentrations were observed in the gills of fish exposed to $\mathrm{CuSO}_{4}$ than Cu-NPs after 10 days (Shaw et al., 2012). At neutral pH at least, Shaw et al. (2012) argued in favour of a greater bioavailability of dissolved $\mathrm{Cu}$ from $\mathrm{CuSO}_{4}$, and likely limited dissolution of soluble $\mathrm{Cu}$ species from $\mathrm{Cu}-\mathrm{NPs}$ at the gill surface. However, in the present study, exposures were also conducted at pH 5. For the $\mathrm{CuSO}_{4}$ treatment, the gills showed less $\mathrm{Cu}$ accumulation at $\mathrm{pH} 5$, compared to the exposure at $\mathrm{pH}$ 7. This observation is consistent with the biotic ligand model, where $\mathrm{H}^{+}$ions with their high ionic mobility in solution compared to all other cations (Handy and Eddy, 1991; Playle and Dixon, 1993), and greater concentration in the present study ( $10 \mu \mathrm{moll}^{-1} \mathrm{H}^{+}$compared to about $0.3 \mu \mathrm{moll}^{-1}$ of total $\mathrm{Cu}$ in the water), should out-compete $\mathrm{Cu}$ for binding sites on the gill. 

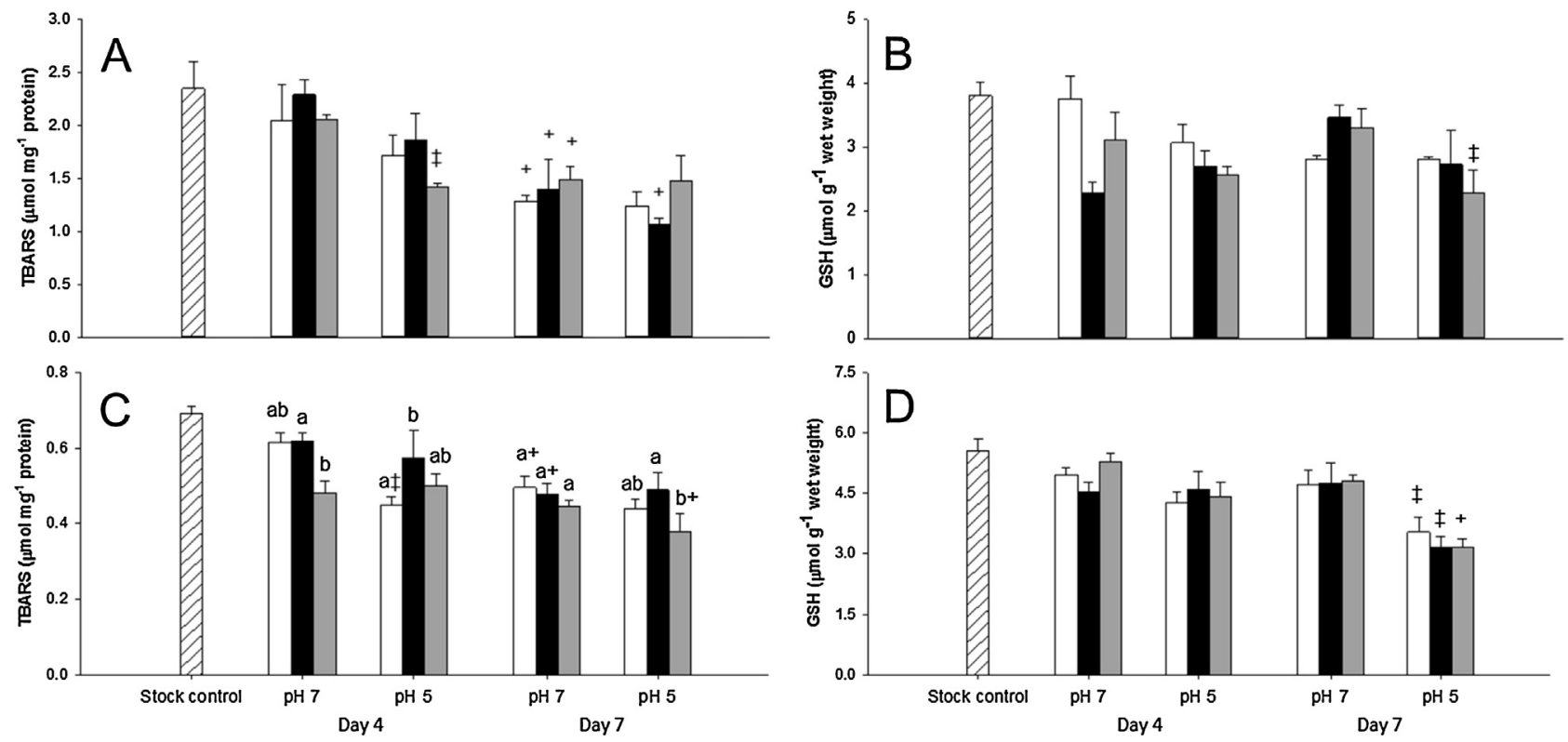

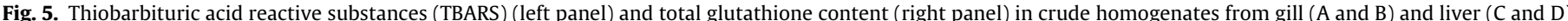

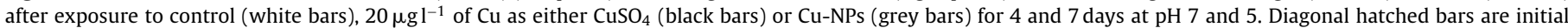

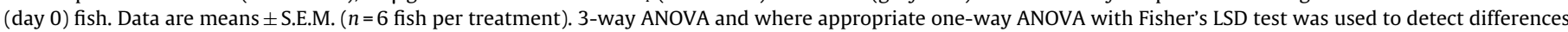

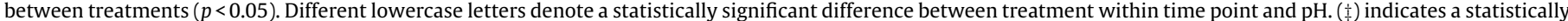

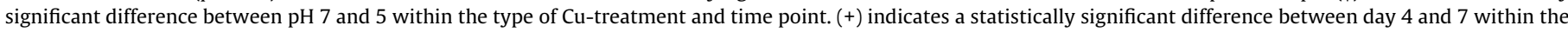
type of $\mathrm{Cu}$-treatment and $\mathrm{pH}$.

In contrast to $\mathrm{CuSO}_{4}$, there was no $\mathrm{pH}$-effect on the accumulation of $\mathrm{Cu}$ in the gill from $\mathrm{Cu}-\mathrm{NP}$ exposures, despite the fact that the physico-chemistry and dialysis experiments indicated a pH-effect on the particles themselves. In the stock dispersions, the primary particle diameter decreased from about $60 \mathrm{~nm}$ at $\mathrm{pH} 7$ to $54 \mathrm{~nm}$ at $\mathrm{pH} 5$, suggesting that the Cu-NPs had partially dissolved in the acid. This was also confirmed by dialysis experiments which showed a greater increase in the total $\mathrm{Cu}$ concentration in the external part of the beaker (Fig. 2), which could be interpreted as increased dissolution of $\mathrm{Cu}$ from $\mathrm{Cu}-\mathrm{NPs}$ at low $\mathrm{pH}$. The mean hydrodynamic diameter of aggregates of particles was also smaller, and with a reduced particle number concentration at $\mathrm{pH} 5$ compared to $\mathrm{pH} 7$ in the stock dispersions (Fig. 1), also supporting the notion of dissolution. However, any apparent dissolution should increase the dissolved $\mathrm{Cu}$ concentration in the water to promote $\mathrm{Cu}$ accumulation in the gill at low $\mathrm{pH}$, but this was not observed with $\mathrm{Cu}-\mathrm{NP}$ exposure (Fig. 3). This phenomenon requires further investigation, but it possible that the high $\mathrm{H}^{+}$concentration at low $\mathrm{pH}$ simply out competes any $\mathrm{Cu}$ ions released from the particles (i.e. the BLM for the dissolved metal fraction is more important than particle chemistry for metal bioavailability). Unfortunately, it was not possible to measure particle size distributions directly from the aquarium water because the exposure concentrations were far below the useful detection limit of NTA, or any other method for measuring particle size distributions (see Handy et al., 2012). It is also possible that the low $\mathrm{pH}$ in the aquarium water increased the polyanionic charge of macromolecules such as humic acids (Plymouth water typically has around $1 \mathrm{mg} \mathrm{l}^{-1}$ of total dissolved organic carbon). This would provide a soft colloid sink (Town et al., 2012) for chelating any $\mathrm{Cu}$ ions released from the $\mathrm{Cu}-\mathrm{NPs}$, resulting in the observed no-effect of $\mathrm{pH}$ on metal accumulation at the gill.

\subsection{Copper accumulation by the internal organs at $\mathrm{pH} 7$ and $\mathrm{pH} 5$}

The body distribution and internal target organs for traditional dissolved forms of $\mathrm{Cu}$ are reasonably understood for studies with radio-labelled ${ }^{64} \mathrm{Cu}$. For teleost fishes in freshwater, $\mathrm{Cu}$ is absorbed across the gill and transferred to the liver as the central compartment for $\mathrm{Cu}$ homeostasis (Grosell et al., 1997, 1998a,b). The liver regulates the biliary excretion of $\mathrm{Cu}$ and therefore only limited amounts of $\mathrm{Cu}$ are passed on to other internal organs (e.g. Kamunde and Wood, 2004). In our previous study, Shaw et al. (2012) showed that exposure to $20 \mu \mathrm{gl}^{-1}$ of $\mathrm{Cu}$ as $\mathrm{CuSO}_{4}$ for 10 days caused measurable increases in the total $\mathrm{Cu}$ concentration in the liver of rainbow trout, but with no detectable increases in the muscle, brain or spleen. Similar observations are made in the present study at the same $\mathrm{Cu}$ concentration at $\mathrm{pH} 7$ with the liver being the only internal organ to show an elevated tissue $\mathrm{Cu}$ concentration by the end of the experiment (Fig. 3). There was a pH-effect, in that the fish exposed at pH 5 did not show an elevated hepatic $\mathrm{Cu}$ concentration (consistent with less accumulation by the gill).

For the $\mathrm{Cu}-\mathrm{NP}$ treatment, no measurable increases in total $\mathrm{Cu}$ in the internal organs were observed, apart from a transient increase in the total $\mathrm{Cu}$ concentration in the liver at day 4 at $\mathrm{pH} 7$, which was also found in the equivalent $\mathrm{CuSO}_{4}$ treatment (Fig. 3). The absence of measurable increases of total $\mathrm{Cu}$ concentrations in the internal organs following $\mathrm{Cu}-\mathrm{NP}$ exposure is also consistent with our previous reports at neutral water pH (Shaw et al., 2012). This may also indicate that the measurable increases in $\mathrm{Cu}$ gill burdens may, at least partially, be from the superficial binding of $\mathrm{Cu}-\mathrm{NPs}$ to the branchial epithelium (i.e. not intracellular $\mathrm{Cu}$ ) and/or mucus; exposure to low $\mathrm{pH}$ water $(\sim \mathrm{pH} 5)$ causes mucus discharges from the gills of salmonids (Ledy et al., 2003). Since there was no observable $\mathrm{Cu}$ accumulation from the $\mathrm{Cu}-\mathrm{NP}$ exposure in the internal organs at $\mathrm{pH} 5$, and only transient changes in the liver at $\mathrm{pH} 7$, a pH-effect cannot be reliably discerned.

\subsection{Haematology and ionoregulatory disturbances during waterborne exposure}

The effects of acid water on the osmoregulation and haematology of trout is well-known. The acute effects include inhibition of active $\mathrm{Na}^{+}$and $\mathrm{Cl}^{-}$influx at the gill, and a general passive leak of electrolytes across the branchial epithelium caused by the disrup- 
tion of paracellular tight junctions (McDonald, 1983; Wood, 1989; Wood et al., 1998). This may result in some haemodynamic changes including the swelling of red blood cells (Weaver et al., 1999). In the present study, fish at $\mathrm{pH} 5$ showed lower plasma $\mathrm{Na}^{+}$and $\mathrm{Cl}^{-}$concentrations and some dilution of red blood cells (Table 1 ), consistent with sub-lethal effects of acid on fishes.

Copper is well known to interfere with sodium balance. Exposure to $\mathrm{CuSO}_{4}$ at neutral $\mathrm{pH}$ causes osmoregulatory dysfunction at the gills, with inhibition of the branchial $\mathrm{Na}^{+} / \mathrm{K}^{+}$-ATPase leading to plasma sodium depletion, and subsequent changes in haematology in trout (Laurén and McDonald, 1985b; Shaw et al., 2012). In the present study, and as expected, inhibition of $\mathrm{Na}^{+} / \mathrm{K}^{+}$-ATPase and depletion of plasma $\mathrm{Na}^{+}$were observed at $\mathrm{pH} 7$ with $\mathrm{CuSO}_{4}$ (Fig. 4; Table 1). Perturbations in tissue concentrations of $\mathrm{K}^{+}$were also observed. Elevation of gill tissue $\mathrm{Na}^{+}$is also consistent with observed plasma $\mathrm{Na}^{+}$depletion and inhibition of branchial $\mathrm{Na}^{+} / \mathrm{K}^{+}-$ ATPase. A similar observation was reported in trout exposed to $\mathrm{CuSO}_{4}$ (Shaw et al., 2012). Nonetheless, there are relatively few reports of the combined effects of acid/dissolved $\mathrm{Cu}$ on the blood of rainbow trout (but see Laurén and McDonald, 1985a; Hughes and Nemcsok, 1988). Of particular note, inhibition of $\mathrm{Na}^{+} / \mathrm{K}^{+}$-ATPase activity was not observed at pH 5 on day 4 and there was only a non-significant trend toward lower activity at day 7 and this is consistent with the lower bioavailability of $\mathrm{Cu}$ at $\mathrm{pH} 5$ and slower rate of gill accumulation over the course of the exposure. In the current study, the effect of lowering the $\mathrm{pH}$ on both $\mathrm{CuSO}_{4}$ and $\mathrm{Cu}-\mathrm{NPs}$ exposed-fish was greater decreases in gill tissue $\mathrm{Na}^{+}$concentrations compared to the $\mathrm{CuSO}_{4}$ and $\mathrm{Cu}-\mathrm{NPs}$ treatment at $\mathrm{pH} 7$; an effect not seen in control fish, at least at day 4 . This means that the osmoregulatory disturbance is altered at lower $\mathrm{pH}$ values.

In our previous study on $\mathrm{Cu}-\mathrm{NPs}$ at neutral $\mathrm{pH}$, rainbow trout showed similar disturbances to the blood as fish exposed to $\mathrm{CuSO}_{4}$, but with some additional transient changes in plasma $\mathrm{Na}^{+}$and haematocrits (Shaw et al., 2012). These effects were mostly within the normal physiological range of trout, and were interpreted as not being clinically significant. The present study is consistent with these findings, with some relative changes in plasma ion concentrations and haematocrits occurring later during the exposure in fish exposed to $\mathrm{Cu}-\mathrm{NPs}$ compared to $\mathrm{CuSO}_{4}$ at $\mathrm{pH}$ 7. Increased haematocrits have also been previously reported in both European perch (Perca fluviatilis; Rask and Virtanen, 1986) and banded sunfish (Enneacanthus obesus; Gonzalez and Dunson, 1987) at low pH and have been suggested to be in response to the decreased oxygen binding-affinity of haemoglobin at acid $\mathrm{pH}$ (the Bohr effect).

Some observations were also made on white blood cell counts. Copper is known to alter immune parameters in the blood of fish (Dethloff and Bailey, 1998) and modulate the immune system (Handy, 2003). Both exposure to acid or $\mathrm{CuSO}_{4}$ alone increased the total white cell count (Table 1), consistent with an immunestimulation or inflammation effect. At low $\mathrm{pH}$, the effect of $\mathrm{CuSO}_{4}$ on the white blood cell count was much greater, doubling the number of cells (Table 1). This implies the effects of acid and $\mathrm{CuSO}_{4}$ are additive. A similar effect was noted with combination of acid/Cu$\mathrm{NPs}$, even though lower $\mathrm{Cu}$ accumulation was noted in the $\mathrm{Cu}-\mathrm{NP}$ treatment. This phenomenon requires further investigation, but may be related to inflammation associated with gill injury from $\mathrm{CuSO}_{4}$ and $\mathrm{Cu}-\mathrm{NPs}$ (Al-Bairuty et al., 2013).

\subsection{Oxidative stress during waterborne exposure}

Oxidative stress is a well-known result of copper exposure (Hoyle et al., 2007; Eyckmans et al., 2011), and has also been reported for acid stress in fish toxicity (e.g. Mai et al., 2010). In the current study, there were mostly no changes in the gill and other internal organs, but some effects on the liver, likely relating to the function of this organ (Fig. 5). Exposure of fish to $\mathrm{CuSO}_{4}$ at $\mathrm{pH} 5$ caused an increase in TBARS levels in the liver, although the glutathione content of the liver was conserved (Fig. 5) and values were similar to controls under other conditions in the experiment (i.e. at $\mathrm{pH} 7$ ). At acidic $\mathrm{pH}$, the liver showed no measurable $\mathrm{Cu}$ accumulation from $\mathrm{CuSO}_{4}$ treatment (Fig. 3), but a systemic hypoxia arising from gill injury due to $\mathrm{Cu}$ (Mustafa et al., 2012) or acid exposure could generate secondary ROS leading to oxidative stress in the liver. Similar disparate effects were also apparent in fish exposed to $\mathrm{Cu}-\mathrm{NPs}$.

\section{Conclusions}

The current study provides one of the first detailed effects of water $\mathrm{pH}$ on the sub-lethal toxicity of $\mathrm{Cu}-\mathrm{NPs}$ in rainbow trout. Overall, our findings demonstrate that the accumulation of $\mathrm{Cu}$ and associated sub-lethal responses in trout were affected by lowering the water $\mathrm{pH}$ from 7 to 5 . It has also indicated that the effects of $\mathrm{Cu}-$ NPs are less or similar to those known for $\mathrm{Cu}$ metal salts at both $\mathrm{pH}$ values. For example, some physiological results ( $\mathrm{Cu}$ accumulation in the gill, haematology and plasma electrolytes) showed that the effect of $\mathrm{CuSO}_{4}$ was greater than $\mathrm{Cu}-\mathrm{NP}$ treatments at both $\mathrm{pH}$ values. This arose from the greater bioavailability of $\mathrm{Cu}$ from $\mathrm{CuSO}_{4}$ compared to $\mathrm{Cu}-\mathrm{NP}$ at both $\mathrm{pH}$ values. Nevertheless, the demonstration that acidic water caused increased metal ion dissolution from Cu-NPs has important implications for our understanding of the fate of Cu-NPs under variable environmental conditions. Salmonids inhabit a range of freshwater environments including acidic and low ionic strength waters that are often typical of upland streams where spawning occur. Understanding how water chemistry affects NP toxicity is therefore necessary for a robust risk assessment approach to nanomaterials in the environment.

\section{Acknowledgements}

Genan A. Al-Bairuty was funded by a PhD studentship from the Iraqi Government, University of Baghdad, College of Education Ibn Al-Haitham, and the experiment was also supported by a NERC grant awarded to Richard D. Handy (NE/G001812/1). Andrew J. Atfield is thanked for technical assistance.

\section{References}

Al-Bairuty, G.A., Shaw, B.J., Handy, R.D., Henry, T.B., 2013. Histopathological effects of waterborne copper nanoparticles and copper sulphate on the organs of rainbow trout (Oncorhynchus mykiss). Aquat. Toxicol. 126, 104-115.

Besinis, A., De Peralta, T., Handy, R.D., 2012. The antibacterial effects of silver, titanium dioxide and silica dioxide nanoparticles compared to the dental disinfectant chlorhexidine on Streptococcus mutans using a suite of bioassays. Nanotoxicology 8, 1-16.

Bowen, H.J.M., 1985. The handbook of environmental chemistry. In: Hutzinger, D. (Ed.), The Natural Environment and Biogeochemical Cycles, vol. 1 Springer-Verlag, New York, pp. 1-26

Bury, N.R., Handy, R.D., 2010. Copper and iron uptake in teleost fish. In: Bury, N.R. Handy, R.D. (Eds.), Surface Chemistry, Bioavailability and Metal Homeostasis in Aquatic Organisms: An integrated approach. Essential Reviews in Experimental Biology. Society for Experimental Biology Press, London, pp. 107-127.

Chevalier, G., Gauthier, L., Moreau, G., 1985. Histopathological and electron microscopic studies of gills of brook trout Salvelinus fontinalis, from acidified lakes. Can. J. Zool. 63, 2062-2070.

Cusimano, R.F., Brakke, D.F., Chapman, G.A., 1986. Effects of pH on the toxicities of cadmium copper, and zinc to steelhead trout (Salmo gairdneri). Can. J. Fish. Aquat. Sci. 43, 1497-1503.

Dethloff, G.M., Bailey, H.C., 1998. Effects of copper on immune system parameters of rainbow trout (Oncorhynchus mykiss). Environ. Toxicol. Chem. 17, 1807-1814

Erickson, R.J., Benoit, D.A., Mattson, V.R., Leonard, E.N., Nelson, H.P., 1996. The effects of water chemistry on the toxicity of copper to fathead minnows. Environ. Toxicol. Chem. 15, 181-193.

Eyckmans, M., Celis, N., Horemans, N., Blust, R., De Boeck, G., 2011. Exposure to waterborne copper reveals differences in oxidative stress response in three freshwater fish species. Aquat. Toxicol. 103, 112-120.

Figueiredo-Fernandes, A., Ferreira-Cardoso, J.V., Garcia-Santos, S., Monteiro, S.M., Carrola, J., Matos, P., Fontaínhas-Fernandes, A., 2007. Histopathological 
changes in liver and gill epithelium of Nile tilapia, Oreochromis niloticus, exposed to waterborne copper. Pesquisa Vet. Brasil. 27, 103-109.

Gonzalez, R.J., Dunson, W.A., 1987. Adaptations of sodium balance to low pH in a sunfish (Enneacanthus obesus) from naturally acidic waters. J. Comp. Physiol. 157B, 555-566.

Griffitt, R.J., Weil, R., Hyndman, K.A., Denslow, N.D., Powers, K., Taylor, D., Barber, D.S., 2007. Exposure to copper nanoparticles causes gill injury and acute lethality in zebrafish (Danio rerio). Environ. Sci. Technol. 41, 8178-8186.

Grosell, M., 2012. Copper. In: Wood, C.M., Farrell, A.P., Brauner, C.J. (Eds.), Homeostasis and Toxicology of Essential Metals. Elsevier Inc., London, pp. 53-133.

Grosell, M., Boetius, I., Hansen, H.J.M., Rosenkilde, P., 1996. Influence of preexposure to sublethal levels of copper on ${ }^{64} \mathrm{Cu}$ uptake and distribution among tissues of the european eel (Anguilla anguilla). Comp. Biochem. Physiol. 114C, 229-235.

Grosell, M.H., Hogstrand, C., Wood, C.M., 1997. Cu uptake and turnover in both Cu-acclimated and non-acclimated rainbow trout (Oncorhynchus mykiss). Aquat. Toxicol. 38, 257-276.

Grosell, M., Hansen, H.J., Rosenkilde, P., 1998a. Cu uptake, metabolism and elimination in fed and starved European eels (Anguilla anguilla) during adaptation to water-borne Cu exposure. Comp. Biochem. Physiol. 120C 295-305.

Grosell, M.H., Hogstrand, C., Wood, C.M., 1998b. Renal Cu and Na excretion and hepatic $\mathrm{Cu}$ metabolism in both $\mathrm{Cu}$ acclimated and non acclimated rainbow trout (Oncorhynchus mykiss). Aquat. Toxicol. 40, 275-291.

Handy, R.D., 2003. Chronic effects of copper exposure versus endocrine toxicity: two sides of the same toxicological process? Comp. Biochem. Physiol. 135A $25-38$.

Handy, R.D., Depledge, M.H., 1999. Physiological responses: their measurement and use as environmental biomarkers in ecotoxicology. Ecotoxicology 8 329-349.

Handy, R.D., Eddy, F.B., 1991. Effects of inorganic cations on sodium adsorption to the gill and body surface of rainbow trout Oncorhynchus mykiss, in dilute solutions. Can. J. Fish. Aquat. Sci. 48, 1829-1837.

Handy, R.D., Eddy, F.B., Romain, G., 1989. In vitro evidence for the ionoregulatory role of rainbow trout mucus in acid, acid/aluminium and zinc toxicity. J. Fish Biol. 35, 737-747.

Handy, R.D., Musonda, M.M., Phillips, C., Falla, S.J., 2000. Mechanisms of gastrointestinal copper absorption in the African walking catfish: copper dose-effects and a novel anion-dependent pathway in the intestine. J. Exp. Biol. 203, 2365-2377

Handy, R.D., van den Brink, N., Chappell, M., Mühling, M., Behra, R., Dušinská, M. Simpson, P., Ahtiainen, J., Jha, A.N., Seiter, J., Bednar, A., Kennedy, A., Fernandes, T.F., Riediker, M., 2012. Practical considerations for conducting ecotoxicity test methods with manufactured nanomaterials: what have we learnt so far? Ecotoxicology 21, 933-972.

Hoyle, I., Shaw, B.J., Handy, R.D., 2007. Dietary copper exposure in the African walking catfish: Clarias gariepinus: transient osmoregulatory disturbances and oxidative stress. Aquat. Toxicol. 83, 62-72.

Hughes, G.M., Nemcsok, J., 1988. Effects of low pH alone and combined with copper sulphate on blood parameters of rainbow trout. Environ. Pollut. 55, 89-95.

Kamunde, C.N., Wood, C.M., 2004. Environmental chemistry, physiological homeostasis, toxicology, and environmental regulation of copper: an essential element in freshwater fish. Aust. J. Ecotoxicol. 10, 1-20.
Laurén, D.J., McDonald, D.G., 1985a. Influence of water hardness, pH, and alkalinity on the mechanisms of copper toxicity in juvenile rainbow trout: Salmo gairdneri. Can. J. Fish. Aquat. Sci. 43, 1488-1496.

Laurén, D.J., McDonald, D.G., 1985b. Effects of copper on branchial ionoregulation in the rainbow trout, Salmo gairdneri Richardson. J. Comp. Physiol. 155B, 635-644.

Ledy, K., Giambérini, L., Pihan, J.C., 2003. Mucous cell responses in gill and skin of brown trout Salmo trutta fario in acidic: aluminium-containing stream water. Dis. Aquat. Organ. 56, 235-240.

Linder, M.C., Hazegh-Azam, M., 1996. Copper biochemistry and molecular biology. Am. J. Clin. Nutr. 63, 797S-811S

Mai, W.J., Yan, J.L., Wang, L., Zheng, Y., Xin, Y., Wang, W.N., 2010. Acute acidic exposure induces p53-mediated oxidative stress and DNA damage in tilapia (Oreochromis niloticus) blood cells. Aquat. Toxicol. 100, 271-281.

McDonald, D.G., 1983. The effects of $\mathrm{H}^{+}$upon the gills of freshwater fish. Can. J. Zool. 61, 691-703

Mustafa, S.A., Davies, S.J., Jha, A.N., 2012. Determination of hypoxia and dietary copper mediated sub-lethal toxicity in carp, Cyprinus carpio, at different levels of biological organisation. Chemosphere 87, 413-422.

Nussey, G., Van Vuren, J.H.J., Du Preez, H.H., 2002. The effect of copper and zinc at neutral and acidic $\mathrm{pH}$ on the general haematology and osmoregulation of Oreochromis mossambicus. Afr. J. Aquat. Sci. 27, 61-84.

Playle, R.C., Dixon, D.G., 1993. Copper and cadmium binding to fish gills: estimates of metal-gill stability contacts and modelling of metal accumulation. Can. J. Fish. Aquat. Sci 50, 2678-2687.

Plonka, A.C., Neff, W.H., 1969. Mucopolysaccharide histochemistry of gill epithelial secretions in brook trout exposed to acid pH. Proc. Natl. Acad. Sci. U. S. A. 43, 53-55.

Rask, M., Virtanen, E., 1986. Responses of perch Perca fluviatilis L., from an acidic and neutral lake to acidic water. Water. Air. Soil Pollut. 30, 537-543.

Shaw, B.J., Al-Bairuty, G.A., Handy, R.D., 2012. Effects of waterborne copper nanoparticles and copper sulphate on rainbow trout (Oncorhynchus mykiss): physiology and accumulation. Aquat. Toxicol. 116-117, 90-101.

Smith, C.J., Shaw, B.J., Handy, R.D., 2007. Toxicity of single walled carbon nanotubes to rainbow trout (Oncorhynchus mykiss): respiratory toxicity, organ pathologies, and other physiological effects. Aquat. Toxicol. 82, 94-109.

Town, R.M., Duval, J.F.L., Buffle, J., van Leeuwen, H.P., 2012. Chemodynamics of metal complexation by natural soft colloids: $\mathrm{Cu}(\mathrm{II})$ binding by humic acid. J. Phys, Chem. A 116, 6489-6496.

Weaver, Y.R., Kiessling, K., Cossins, A.R., 1999. Responses of the $\mathrm{Na}^{+} / \mathrm{H}^{+}$exchanger of European flounder red blood cells to hypertonic, $\beta$-adrenergic and acidotic stimuli. J. Exp. Biol. 202, 21-32.

Wood, C.M., 1989. The physiological problems of fish in acid waters. In: Morris, R. Brown, D.J.A., Taylor, E.W., Brown, J.A. (Eds.), Acid Toxicity and Aquatic Animals. Cambridge University Press, Cambridge, pp. 125-152.

Wood, C.M., Mcdonald, D.G., 1982. Physiological mechanisms of acid toxicity to fish. In: Johnson, R.E. (Ed.), Acid Rain/Fisheries: Proceedings of the Internationa Symposium on Acid Precipitation and Forest. Impacts in North-Eastern North America. American Fisheries Society, Bethesda, pp. 197-226.

Wood, C.M., Wilson, R.W., Gonzalez, R.J., Patrick, M.L., Bergman, H.L., Narahara, A., Val, A.L., 1998. Responses of an Amazonian teleost the tambaqui (Colossoma macropomum), to low pH in extremely soft water. Physiol. Zool. 71, 658-670. 